\title{
Nonalcoholic Fatty Liver Disease (NAFLD) as Model of Gut-Liver Axis Interaction: From Pathophysiology to Potential Target of Treatment for Personalized Therapy
}

\author{
Francesca Fianchi ${ }^{1,2} \mathbb{D}$, Antonio Liguori ${ }^{1,2} \mathbb{D}$, Antonio Gasbarrini ${ }^{1,2}$, Antonio Grieco ${ }^{1,2}$ and Luca Miele ${ }^{1,2, *(\mathbb{D})}$ \\ 1 Dipartimento di Scienze Mediche e Chirurgiche, Fondazione Policlinico Universitario A. Gemelli IRCCS, \\ 00168 Rome, Italy; francesca.fianchi@gmail.com (F.F.); lig.antonio91@gmail.com (A.L.); \\ Antonio.gasbarrini@unicatt.it (A.G.); antonio.grieco@unicatt.it (A.G.) \\ 2 Dipartimento Universitario di Medicina e Chirurgia Traslazionale, Università Cattolica del S. Cuore, \\ 00168 Rome, Italy \\ * Correspondence: luca.miele@policlinicogemelli.it or luca.miele@unicatt.it
}

check for

updates

Citation: Fianchi, F.; Liguori, A.; Gasbarrini, A.; Grieco, A.; Miele, L. Nonalcoholic Fatty Liver Disease (NAFLD) as Model of Gut-Liver Axis Interaction: From Pathophysiology to Potential Target of Treatment for Personalized Therapy. Int. J. Mol. Sci. 2021, 22, 6485. https://doi.org/ $10.3390 /$ ijms 22126485

Academic Editor: Takemi Akahane

Received: 22 May 2021

Accepted: 14 June 2021

Published: 17 June 2021

Publisher's Note: MDPI stays neutral with regard to jurisdictional claims in published maps and institutional affiliations.

Copyright: (c) 2021 by the authors. Licensee MDPI, Basel, Switzerland. This article is an open access article distributed under the terms and conditions of the Creative Commons Attribution (CC BY) license (https:// creativecommons.org/licenses/by/ $4.0 /)$.

\begin{abstract}
Nonalcoholic fatty liver disease (NAFLD) is the leading cause of liver disease worldwide, affecting both adults and children and will result, in the near future, as the leading cause of end-stage liver disease. Indeed, its prevalence is rapidly increasing, and NAFLD is becoming a major public health concern. For this reason, great efforts are needed to identify its pathogenetic factors and new therapeutic approaches. In the past decade, enormous advances understanding the gut-liver axis-the complex network of cross-talking between the gut, microbiome and liver through the portal circulation-have elucidated its role as one of the main actors in the pathogenesis of NAFLD. Indeed, evidence shows that gut microbiota is involved in the development and progression of liver steatosis, inflammation and fibrosis seen in the context of NAFLD, as well as in the process of hepatocarcinogenesis. As a result, gut microbiota is currently emerging as a non-invasive biomarker for the diagnosis of disease and for the assessment of its severity. Additionally, to its enormous diagnostic potential, gut microbiota is currently studied as a therapeutic target in NAFLD: several different approaches targeting the gut homeostasis such as antibiotics, prebiotics, probiotics, symbiotics, adsorbents, bariatric surgery and fecal microbiota transplantation are emerging as promising therapeutic options.
\end{abstract}

Keywords: microbiota; NAFLD; MAFLD; NASH; hepatocarcinoma

\section{Introduction}

The human gut microbiota comprises the trillions of microorganisms from 500 to 1000 different species that reside in our gastrointestinal (GI) tract, of which bacteria constitute the vast majority [1,2]. This large community of microbes establishes a symbiotic relationship with the host and is able to perform various functions that significantly influence its physiology and pathology. Indeed, the gut microbiota has recognized to play many important roles in the mammalian body such as dietary nutrient metabolism and energy extraction, immune system education and tolerance development and the prevention of pathogen colonization [3-5]. For this reason, disturbance of its homeostasis may be involved in the development of several different diseases.

Studies of the human microbiome revealed that the population of microbes inhabiting the gut have an interpersonal variation and temporal fluctuations in composition even in healthy individuals; much of this diversity remains unexplained although diet, environment, host genetics, antibiotics, lifestyle factors and early microbial exposure have all been implicated [6,7].

In the past decade a close relationship between gut microbiota homeostasis and liver diseases has been described [8-10]. In fact, the liver receives $75 \%$ of its blood supply from 
the intestinal portal circulation and provides first-pass metabolism for the GI luminal contents: These include dietary nutrients as well as toxins and xenobiotics that translocate across the intestinal epithelium [11]. Several different studies have described a beneficial role of the commensal microbiota in maintaining liver homeostasis and preventing liver fibrosis [12]. As such, a disturbed imbalance of the endogenous microbiota, otherwise known as dysbiosis, has been associated with a range of chronic liver conditions such as NAFLD, nonalcoholic steatohepatitis (NASH), alcoholic liver disease (ALD) [13] as well as cirrhosis and its complications (hepatic encephalopathy (HE), HCC) [14-17].

On the other hand, it is well known that liver diseases can alter the gut microbiota, in a mutual relationship in which the two systems are able to influence each other. For this reason, authors have started to talk about the existence of a "gut-liver axis" [18,19].

\section{Gut Microbiome and NAFLD}

NAFLD is estimated to affect up to one-third of the adult population in many developed and developing countries, and its global incidence is continuously rising along with the global rise of obesity and metabolic syndrome [20].

Indeed, NAFLD should be considered as a spectrum of chronic liver diseases that ranges from simple steatosis to NASH and cirrhosis [21]. NAFLD is considered to be the hepatic manifestation of metabolic syndrome. For this reason, a group of experts has recently suggested a change in nomenclature for these conditions that could better reflect the pathogenesis and the heterogeneity of patients: metabolic (dysfunction) associated fatty liver disease "MAFLD" has been proposed [22].

The pathophysiology is multifactorial, involving genetic and epigenetic factors, insulin resistance, hormones secreted from the adipose tissue and nutritional factors [23]. The result of this multiple-hit pathogenesis is a lipid accumulation in the hepatocytes with consequent oxidative stress, lipid peroxidation, adipokine signaling and pro-inflammatory cytokine expression [24]. In addition to the well-known risk factors for the disease (genetics, Western diet and sedentary lifestyles), the important role played by the gut microbiota and its metabolites has increasingly emerged [25]. In fact, a growing body of evidence suggests that the gut microbiota is able to modulate the gut-liver axis [26-28].

Both animal and human studies have identified compositional changes in gut microbiota in association with NAFLD-spectrum diseases, although some contrasting evidence has emerged. Indeed, hepatic steatosis has been associated with a reduced diversity of the microbiota population inhabiting the gut. At the phylum level, an increase in Firmicutes and a reduction in Bacteroidetes is commonly described in NAFLD, although diverging results have been described at the class, order, family and genus levels [29].

An elegant study from Raman et al. compared 30 NAFLD patients and 30 healthy controls, finding increased Lactobacillaceae, Lachnospiraceae and Veillonellaceae, but decreased Ruminococcaceae in NAFLD patients [30]. Mouzaki et al. found that patients with NASH had a lower percentage of Bacteroidetes compared to both patient with NAFLD and healthy controls [31]. Zhu et al. demonstrated that children with biopsy-proven NASH had significant difference in gut microbiota composition compared to children with obesity alone: in particular, authors found increased Bacteroidetes in NASH, in contrast to results by Mouzaki [32].

Examining all the data emerged from human studies, certain taxonomic changes have been observed in association with NAFLD but several controversies regarding the microbiome profile in this population are still existing-likely due to differences in experimental design - and no consistent microbiota signature has been identified yet [33].

On the other hand, changes in bacterial taxonomy might not be as important as changes in bacterial genes (metagenomics and metatranscriptomics) in the pathogenesis of NAFLD: In fact, the complex interactions between the enteric microbiome and the host are often mediated by metabolites. In a recent study conducted by Qian et al. in mice, it was demonstrated, for example, that the transcriptional landscape changes dramatically in mice with NASH when compared to mice with isolated steatosis. Plasma lipidome 
analysis demonstrated a very clear difference between these two groups of mice, which was partially recapitulated in serum of patients with isolated steatosis and NASH [34].

In detail, NAFLD and its severity seem to be associated with a greater abundance of genes encoding inflammatory bacterial products [35].

A great challenge at this point was to establish whether dysbiosis could play a causal role or rather represent an epiphenomenon of the disease. To this end, several studies have investigated the potential causal relationship between microbiota and NAFLD: Animal studies in which the gut microbiota is manipulated and observational studies in patients with NAFLD have provided considerable evidence that dysbiosis contributes to the pathogenesis of NAFLD. A crucial murine investigation conducted by Le Roy et al. demonstrated that the risk of developing NAFLD is transmissible by fecal transplant to recipient mice: Indeed, gut microbiota transplantation from a mouse that had previously showed a metabolic response to high-fat diet to germ-free mice produced hyperglycemia, hyperinsulinemia and hepatic steatosis. On the other hand, mice accepting microbiota from a donor mouse that had not developed a metabolic response to high-fat diet, remained normoglycemic and did not develop steatosis. Interestingly, these results were independent from weight gain, which had been comparable between the two donors. The characterization of the transplanted microbiotas revealed significant differences at the phyla, genera and species levels, highlighting the role of dysbiosis [36]. A human study by Vrieze et al. demonstrated that transfer of intestinal microbiota from lean donors could increase insulin sensitivity in individuals with metabolic syndrome, along with increased levels of butyrate-producing intestinal microbiota [37].

Interestingly, gut dysbiosis seems to be implicated not only in the development of NAFLD but also in the severity of disease and its progression to NASH and, eventually, cirrhosis [38]. Boursier et al. examined the gut microbiota taxonomic composition of patients with biopsy proven NAFLD and different degrees of fibrosis: The results showed how Bacteroidetes abundance was significantly higher in NASH, whereas Prevotella abundance was lower; Ruminococcus abundance was significantly higher in $\mathrm{F} \geq 2$ patients [39]. As a result, these two genera of bacteria seem independently correlated to the severity of disease. These results were compliant with the previously cited study from Mouzaky et al. [31]. A case series by Bastian et al. highlighted how gut microbiota profiles in NAFLD seem to affect disease progression in terms of liver fibrosis, evaluated with transient elastography [40]. A recent cross-sectional study conducted in children described how fecal microbiomes of patients with NAFLD have lower $\alpha$-diversity than those of control children, and among them, children with NASH have the lowest $\alpha$-diversity. When considering the microbial populations, a high abundance of Prevotella copri was associated with more severe fibrosis [35].

Several different mechanisms have proposed to explain the role of the gut microbiota in the pathogenesis of NAFLD, including a dysbiosis-induced increased intestinal permeability (the "leaky gut"), an increased dietary energy harvest, the regulation of choline metabolism, the production of short chain fatty acids (SCFAs) and the bile acids metabolism [Figure 1]. 


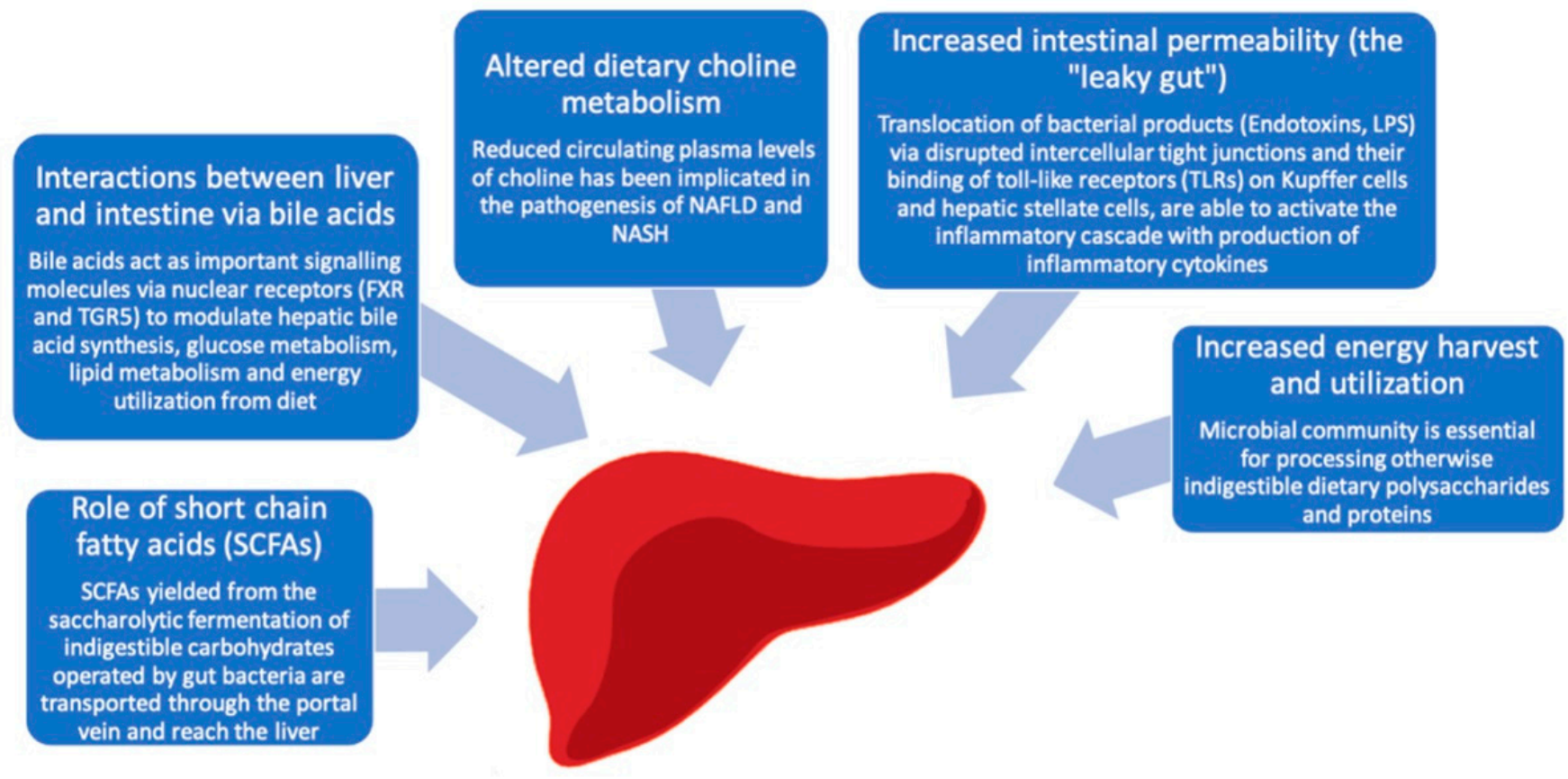

Figure 1. Gut microbiota related mechanisms implicated in the pathogenesis of NAFLD/NASH. Intestinal microbiota can contribute to the development of hepatic steatosis through a variety of mechanisms, including an increased intestinal permeability, effects on appetite regulation and energy extraction from the diet and modulation of bile acids signaling.

\subsection{The "Leaky Gut"}

Dysbiosis has been associated with a dysregulation of gut endothelial barrier function, with enhanced intestinal permeability to microbes and/or microbial products (endotoxins, lipopolysaccharide [LPS], peptidoglycan) that enter the portal circulation with an increased hepatic exposure to injurious substances, potentially leading to hepatica inflammation and fibrosis [41,42]. Indeed, translocated bacteria or their products are important mediators of liver inflammation and fibrosis by binding to receptors of the innate immune system on the liver cells [43]. The abundance of this microbial product in the portal circulation elicits host immunological responses through the activation of toll-like receptors (TLRs) on Kupffer cells and hepatic stellate cells, with consequent activation of the inflammatory cascade and production of inflammatory cytokines such as tumor necrosis factor (TNF) $\alpha$, interleukin (IL)-1 $\beta$ and interferons [44].

Among the TRLs family, TLR2, TRL4, TRL5 and TRL9 are implicated in the pathogenesis of NAFLD [45]. TLR4 is involved in NAFLD development through its binding with LPS and activation of NF-kB pathway $[46,47]$, as demonstrated by the fact that mutant mice with a disruption of the LPS-TLR4 signaling pathway (TLR4 mutant mice) are resistant to liver injury and fibrosis, as well as being protected against diet-induced obesity and insulin resistance [48-50]. Consistent with histological findings in the liver, the expression of proinflammatory cytokines is suppressed in TLR4 mutant mice, even in the presence of equivalent LPS levels. In another study, TLR9 promoted steatohepatitis by the induction of (IL) $-1 \beta$ in mice [51]. Indeed, even though gut microbiota represents a source of TLR ligands, in healthy livers there is a high tolerance to the TRL ligand because hepatic cells express minimal TLRs. In contrast, TLR signaling is activated and downstream molecules are increased in NAFLD due to a disrupted immunological tolerance.

This inflammatory milieu represents the first line of defense against the invading pathogens; however, sustained elevation of these cytokines injures the host. Indeed, the presence of portal inflammation in NAFLD may contribute directly to fibrogenesis and is strongly related to disease severity [52].

The molecular mechanisms underlying the increased gut permeability are described in detail in NAFLD. In particular, the translocation occurs via disrupted intercellular tight 
junctions [53]. In murine models, it has been demonstrated that the loss of junctional adhesion molecule A induced by a high-fat diet promotes severe steatohepatitis [54]. In a colitis model induced by dextran sulfate sodium (DSS) in mice, bacterial endotoxins have shown to promote NASH progression [55]. In human models, Miele et al. showed enhanced intestinal permeability related to a decreased expression of zonula occludens-1 (ZO-1), a protein involved in mucosal tight junctions [56].

Indeed, the proven association between gut barrier dysfunction and NAFLD development does not necessarily imply causation, thus it is not clear whether increased intestinal permeability should be considered as a cause or rather a consequence of NAFLD, and further studies are needed to address this major issue. On the other hand, some evidence suggest that early-phase hepatic injury and inflammation are able to contribute to intestinal permeability in a vicious circle. In a meta-analysis of five studies recruiting 128 NAFLD patients, $39.1 \%$ of NAFLD patients showed an increased intestinal permeability compared with $6.8 \%$ of healthy controls, and the rate of patients with gut barrier dysfunction arose as high as $49.2 \%$ when the NASH subgroup was analyzed. In order to further address the underlying mechanism of action, the authors studied changes in intestinal permeability in a diet-induced (methionine-and-choline-deficient; MCD) murine model of NASH: They showed that liver injury is induced early in the course of the MCD diet, before any change in intestinal permeability occurs, suggesting that early changes in liver physiology may affect intestinal homeostasis and contribute to the intestinal permeability [57]. Accordingly, in another study from Giorgio et al., intestinal permeability, as measured through lactulose-mannitol test, appeared to be higher in children with NASH than in children with NAFLD [58].

\subsection{Increased Dietary Energy Harvest and Utilization by the Microbiota}

The gut microbiota plays a key role in regulating the amount of energy extracted from dietary food: indeed, the microbial community is essential for processing otherwise indigestible dietary polysaccharides and proteins by providing a variety of enzymes required for their metabolism [59]. Microorganisms harboring the colon can ferment starch, unabsorbed sugars, cellulosic and non-cellulosic polysaccharides and mucins into shortchain fatty acids (SCFAs) and gases such as carbon dioxide $\left(\mathrm{CO}_{2}\right)$, methane $(\mathrm{CH} 4)$ and hydrogen $(\mathrm{H} 2)[60,61]$. The result of these metabolic reactions is an increased absorption of monosaccharides from the gut lumen.

A close relationship between intestinal microbiota composition and obesity has also been described, both in experimental and in human models. Indeed, the gut microbiota community has been shown to differ between obese mice and their lean littermates, as well as between obese and lean human volunteers [62]; in particular, obesity has been associated with increased Firmicutes rate and decreased Bacteroidetes rate [63]. Consequent metagenomic and biochemical analyses explained how these changes may influence the metabolic potential of the gut microbiota: The obese microbiome, in fact, showed an increased capacity to harvest energy from the diet, with consequent elevated caloric absorption and induction of de novo hepatic lipogenesis [64]. In addition, these enteric bacteria are able to suppress the synthesis of fasting-induced adipocyte factor (Fiaf; also known as angiopoietin-like 4), resulting in the increased activity of lipoprotein lipase (LPL) and the consequent accumulation of triglycerides in the liver. This process provides a direct link between the intestinal microbiota and fat deposition in the liver.

Interestingly, this trait is transmissible, as demonstrated by the fact that colonization of germ-free mice with an 'obese microbiota' results in a significantly greater increase in total body fat than colonization with a 'lean microbiota' [65].

\subsection{Altered Dietary Choline Metabolism by the Microbiota}

Choline is another important metabolite that is involved in the pathogenesis of NAFLD and NASH: choline deficiency in the diet has been linked to liver diseases for a long 
time and choline-deficient diets have historically been used to create rodent models of NASH [66].

Subsequently it has been described how choline deficiency could occur under pathophysiologic conditions, and an association with the gastrointestinal microbiome composition has been described [67]. Indeed, it has been demonstrated that high-fat diets in mice are conducive to the development of an intestinal microbiota with the ability to convert dietary choline into methylamines, with consequently low circulating levels of plasma phosphatidylcholine and high urinary excretion of methylamines (dimethylamine, trimethylamine and trimethylamine-N-oxide) [68]. As a result, the reduced circulating plasma levels of choline mimic the effect of choline-deficient diets, contributing to the development of NAFLD. This microbiota-related reduced choline bioavailability may result in the inability to synthesize phosphatidylcholine, which is necessary for the assembly and secretion of very-low-density lipoprotein (VLDL) [69], therefore resulting in triglyceride accumulation in hepatocytes.

Interestingly, microbiota-induced choline deficiency has also been associated with atherosclerosis and cardiovascular disease [70,71].

\subsection{The Role of SCFAs}

There is a growing interest in the pathogenesis of NAFLD by short chain fatty acids (SCFAs) (i.e., propionate, acetate, butyrate) yielded from the saccharolytic fermentation of indigestible carbohydrates operated by gut bacteria [72]. In fact, although most SCFAs are used in the gut as source of energy, some amount is transported through the portal vein and reaches the liver. In particular, while butyrate is the preferred nutrient for epithelial colonic cells, substantial amounts of propionate are absorbed into the bloodstream and transported to the liver, where it serves as a substrate for gluconeogenesis and cholesterol synthesis. Acetate is the principal SCFA in the blood and is an important energy source to peripheral tissues, including the liver, where it is used for lipogenesis and cholesterol synthesis [73].

SCFAs have been widely related to obesity $[74,75]$, through several different mechanisms such as appetite regulation, energy harvesting and expenditure, insulin resistance, adipose tissue metabolism and diabetes development [76,77]. SCFAs exert their metabolic activity through their binding to G-protein-coupled receptors: they have been demonstrated to represent potent signaling molecules when binding to receptors such as GPR41, GPR43 and GPR109A. One of the mechanisms by which SCFAs affect fat accumulation both in the liver and in the adipose tissue is regulation of insulin sensitivity via GPR43 [78], a metabolite-sensing receptor that heavily influence inflammatory responses through the regulation of the inflammasome $[79,80]$.

Once establishing their role in the development of obesity, SCFAs have been observed to be involved in NAFLD, even though their exact role in the pathogenesis of the disease remains unclear. Rau et al. found higher fecal SCFAs concentrations and a domination of SCFAs-producing bacteria in NAFLD patients when compared to healthy controls, and SCFAs concentrations were associated with immunological features of NAFLD disease progression toward NASH [81].

\subsection{Interactions between Liver and Intestine via Bile Acids}

Bile acids (BA) are endogenous molecules well known for their effects on cholesterol homeostasis and lipid digestion. In addition to facilitating fat absorption, bile acids also act as signaling molecules via nuclear and plasma membrane receptors, of which there are the farnesoid X receptor (FXR) and the Takeda G-protein coupled receptor clone 5 (TGR5). With the identification of these molecular pathways, further roles have been elucidated for bile acids including glucose and lipid metabolism as well as having a role in atherosclerosis, insulin sensitization, inflammation and liver fibrosis development [82-84]. Indeed, by binding to the FXR and TGR5, bile acids are able to increase insulin sensitivity and decrease hepatic gluconeogenesis and circulating triglycerides. 
Due to the aforementioned role in metabolism, BA are involved in the pathogenesis of several metabolic disease, including obesity, type 2 diabetes, dyslipidemia and NAFLD [85].

A key role of gut bacteria in the metabolism of bile acids has been well recognized and widely described, influencing BA production and composition as well as their conversion into secondary bile acids and their enterohepatic circulation, in an FXR-dependent manner [86]. Conversely, bile acids can shape the gut microbiota composition both directly via antibacterial activity and indirectly via FXR, in a well-balanced equilibrium [87-89]. In detail, the gut microbiota regulates expression of several enzymes involved in bile acid synthesis, including CYP7A1, CYP7B1 and CYP27A1. After their synthesis from cholesterol, the liver conjugates bile acids with glycine or taurine: The synthesis of taurine as well as bile acid acyl-CoA-synthetase, which is the first of two enzymes required for bile acid conjugation, is also under microbial regulation. In addition, the gut microbiota may not only regulate the synthesis and conjugation of bile acids, but also their intestinal uptake through the regulation of apical sodium dependent bile acid transporter (ASBT), the main receptor responsible for the enterohepatic circulation of BA [90,91]. Finally, the gut microbiota is also responsible for their metabolism: Indeed, microbial deconjugation (i.e., removal of the glycine or taurine conjugate) that prevents active reuptake from the small intestine is carried out by intestinal bacteria [92].

NAFLD-related dysbiosis has been associated with an altered homeostasis of the bile acids, which in turn increases the risk of hepatic injury. Indeed, dysbiosis may alter the amount and composition of the bile acid pool, resulting in the reduced signaling of bile acid receptors such as FXR and TGR5.

Mouzaki et al. observed a higher synthesis of bile acids in patients with NAFLD compared to healthy controls, as well as a higher primary to secondary bile acids ratio [93]. Jiao et al. confirmed an elevated bile acids production in NAFLD; they also described how NAFLD-associated gut microbiota had increased abundance in Escherichia and Bilophila, both able to metabolize taurine and glycine, with increased production of secondary bile acids. However, despite the elevated production of bile acids, a suppressed hepatic bile acid signaling was described, highlighting the role of the membrane receptors in the pathogenesis of NAFLD [94]. Yang et al. found that patients with NAFLD had lower expressions of FXR in the liver and elevated levels of triglyceride synthesis [95], suggesting that decreased FXR activity is an important factor in the pathogenesis of fatty liver.

The molecular mechanisms by which FXR protects the liver from developing NAFLD are related not only to its role in regulating lipid metabolism but also in suppressing liver inflammation cascade: In particular, FXR exerts its anti-inflammatory effects via antagonizing NF- $\mathrm{kB}$ function and inducing acute phase response proteins $[96,97]$.

\subsection{Dietary Modification of Microbiota}

It has been widely reported how dietary intake represents one of the main determinants of the gut microbiome composition, and diet-induced modifications of the microbiome are able to produce dramatic changes in metabolism of the host [98,99]. Indeed, the diet and the intestinal milieu interact in a complex way with the bacterial population in the gut: For example, dietary intake of fibers lead to high amounts of SCFAs and lowers the $\mathrm{pH}$ in the colon, which in turn affects the composition of the colonic microbiota and thereby the SCFA production. Evidence also suggests that certain food components, which are able to influence the severity of NAFLD, do so at least in part by changing the gut microbiota. For example, one study by Zeng et al. found that a high-fat diet (HFD) in mice led to increased hepatic lipid accumulation and inflammatory cell infiltration that were associated with increased abundance of Lactobacillus acidophilus [100]. It is believed that the Western diet, with its reduced content of indigestible carbohydrates and an increased fat and protein amount, may alter the pool of gut microbial metabolites shifting from saccharolytic to proteolytic fermentation [101,102]. Therefore, there is a larger amount of protein-derived metabolites such as hydrogen sulfide, ammonia and phenolic compounds, which have shown to exert detrimental effects on gut permeability and might indirectly contribute to 
NAFLD facilitating toxic molecules drainage into the portal blood [103,104]. By contrast, indole, specifically derived from the microbial metabolism of L-tryptophan, has shown to decrease gut inflammation as well as preventing gut barrier dysfunction [105]. Of note, in a study conducted in mice, oral administration of indole shaped LPS-induced inflammation through downregulation of the NF-kB pathway in the liver [106].

\section{NAFLD, Microbiota and Hepatocellular Carcinoma (HCC)}

Metabolic liver disease dramatically increases the prevalence of hepatocellular carcinoma (HCC) $[107,108]$, as demonstrated by the fact that NAFLD is the most rapidly growing indication for liver transplantation in patients with HCC [109]. Of note, nonalcoholic steatohepatitis can promote hepatocarcinogenesis even in the absence of cirrhosis [110]; consequently, NAFLD-HCC can escape tumor surveillance, and is more often diagnosed at a later tumor stage [111].

The pathogenesis of NAFLD-associated HCC is a complex landscape, involving several different mechanisms such as immune and inflammatory responses, DNA damage, oxidative stress and autophagy [112-115]. The gut microbiome is involved in most of these mechanisms, being one of the main protagonists of hepatocarcinogenesis [116]. For example, endotoxin accumulation, which is mediated by an altered gut microbiota, prevents carcinogen-induced apoptosis and promotes liver tumorigenesis through the modulation of the immune response, as demonstrated by the fact that circulating levels of LPS are elevated in animal models of HCC and prolonged treatment with low-dose LPS significantly increases HCC development [117]. Indeed, the interaction between LPS and toll-like receptor 4 (TLR4) is crucial in the initiation and promotion of hepatocarcinogenesis through inflammation, chronic liver injury and fibrosis [118]. Conversely, the reduction of LPS trough intestinal decontamination with antibiotics, gut microbiota modulation by probiotics or genetic ablation of its receptor toll-like receptor 4 (TLR4) in mice are protective against tumor growth, representing potential targets for HCC prevention [119].

Another mechanism by which gut bacteria may contribute to hepatocarcinogenesis is through the modulation of bile acid metabolism [120]: Yamada et al., in an experimental model of NASH, suggested that the critical role of the gut microbiota in the conversion of primary to secondary bile acids is involved in HCC development [121].

Moving from this pre-clinical evidence, a study conducted in humans described how HCC development in NAFLD-related cirrhosis is associated with specific gut microbiota profiles and with systemic inflammation. Indeed, patients showed increased levels of fecal calprotectin as well as higher levels of inflammatory cytokines when compared to patients without HCC. When considering the gut microbiota profile, Bacteroides and Ruminococcaceae were increased in the HCC group, while Bifidobacterium were reduced. These results suggest that the gut microbiota composition is significantly related to systemic inflammation, and that it may be involved in hepatocarcinogenesis [122].

\section{Diagnostic Potential of Gut Microbiota}

As extensively reported gut microbiota is involved not only in NAFLD development, but also in its progression and severity, and for this reason it may be considered as a promising non-invasive marker of disease. In assessing whether the severity of NAFLD is associated with gut dysbiosis, the above-mentioned study from Boursier et al. identified Bacteroides as independently associated with NASH and Ruminococcus with significant fibrosis [39]. In another study, adult patients with NASH had a significantly higher percentage of Clostridium coccoides than patients with NAFLD [31]. The analysis conducted from Bastian et al. found significant differences in the composition of gut microbiota in NAFLD patients based on the stages of liver fibrosis, suggesting, for example, that the proportion of Bacteroides can represent a marker of significant liver fibrosis [40].

Given the association between specific microbial populations and NASH, as long as liver fibrosis, a strong rationale exists for the development of a panel of gut-microbiomederived biomarkers that could predict the presence of advanced fibrosis. Moving from this 
evidence, a study conducted by Loomba et al. provides the preliminary evidence for a fecalmicrobiome-derived metagenomic signature to detect advanced fibrosis in NAFLD [123]. Thus, gut microbiota composition analysis adds information to the classical predictors of NAFLD severity and for this reason can represent a main protagonist in the great challenge of noninvasive assessment of liver disease severity.

\section{Therapeutic Potential of Gut Microbiota}

There is currently no medical treatment or drug approved for NAFLD/NASH other than dietary and lifestyle recommendations, although some promising trials are ongoing. In the recent years, modulation of the gut microbiota has been proposed as a new promising therapeutic approach in NAFLD, and the effectiveness of therapies such as antibiotics, probiotics, prebiotics, synbiotics, absorbents, anti-inflammatory drugs and fecal microbiota transplantation have been assessed in several studies [124].

\subsection{Antibiotics}

Antibiotics administration, with the aim of reducing the enteric burden of bacteria and the translocation of microbial components has been extensively studied in NAFLD [125]. In particular, Rifaximin, a non-absorbable antibiotic acting on Gram-negative bacteria, has been shown to exert beneficial effects in patients with NAFLD/NASH, due to its role in lowering endotoxaemia and proinflammatory cytokine production [126-128]. In addition, Rifaximin seems to exert an "eubiotic role", being capable of inducing the overgrowth of beneficial bacteria such as Bifidobacterium, Faecalibacterium and Lactobacillus and so exerting an anti-inflammatory effect [129].

\subsection{Prebiotics}

Prebiotics are indigestible substrates that promote the growth of beneficial bacteria in the gastrointestinal tract that, in preclinical studies, have shown a role in improving the biochemical and histologic markers of NAFLD [130,131]. Despite their safety profile and low cost, only limited studies on the efficacy of prebiotics in NAFLD have been conducted in humans so far [132-137], each one with a small sample size, and some of them not even including patients with histologic confirmation of NAFLD. Moreover, in all of these studies, the impact of prebiotics has been assessed using biochemical markers of liver injury or indices of metabolic dysregulation [138]. Larger clinical trials are currently ongoing, having the impact of prebiotics on steatosis and fibrosis determined by histology or imaging studies as their primary outcome.

\subsection{Probiotics}

Probiotics are living microorganisms that in adequate amounts are able to confer a health benefit to the host via competitive colonization and by acidification of the gastrointestinal lumen, with consequent improvement of the mucosal integrity. Several clinical trials have been conducted on humans in order to evaluate the effect of probiotics on NAFLD/NASH [139-148]: The vast majority of these studies have reported an improvement in serum surrogate markers of disease. Unfortunately, as in the case of prebiotics, only few studies have examined the effect of probiotics on histologic features and, for this reason, their role as a standard therapy in NAFLD/NASH has not been established yet.

Moreover, probiotics seem to have a positive effect in animal models of HCC: in fact, due to their protective effects on intestinal barrier function and their immunomodulatory activity, probiotics are capable of reducing the tumor burden and its inflammatory milieu and can be proposed as a promising weapon in the therapy of NAFLD-related HCC $[149,150]$. However, human studies are necessary for translating this evidence into clinical practice. 


\subsection{Symbiotics}

Symbiotics are a combination of both a prebiotic and a probiotic that currently represent an area of great therapeutic research in NAFLD. Early studies suggested a role in improving both the biochemical and histological features of NAFLD, as well as in ameliorating the overall metabolic profile (in terms of anthropometric indices, lipid profiles and glucose homeostasis parameters) [151-157]. However, the results of a recent clinical trial (the INSYTE study) were not encouraging in promoting synbiotics as a standard therapy for NAFLD: Indeed, 1 year of administration of a synbiotic combination improved the fecal microbiome but did not reduce liver fat content or markers of liver fibrosis [158].

\subsection{Metformin}

Another possible approach involves drugs with anti-inflammatory effects, with the aim of reducing both the intestinal and systemic inflammation. For example, Metformin has been revealed to act as a potent anti-inflammatory drug through a modulation of the gut microbiota [159-161]: In particular, it is able to produce a favorable change in the gut microbiota composition, with an increase in the relative abundance of Bifidobacterium and Akkermansia [162]. Interestingly, Metformin has been associated with a reduced incidence of HCC in preclinical models of NAFLD, probably another effect related to its anti-inflammatory properties [163]. However, currently available human studies of metformin in NAFLD/NASH found no difference from placebo in terms of steatosis, fibrosis, NAFLD activity score or resolution of NASH [164-168].

\subsection{Bile acid Homeostasis Targeting}

As already mentioned, there is a great interplay between intestinal microbiota and bile acids, each one being able to influence the other, and for this reason bile acid homeostasis has been targeted for the treatment of NAFLD. Obeticholic acid (OCA), a steroidal semisynthetic derivative of chenodeoxycholic acid and a potent FXR agonist, has shown to reduce liver fat and fibrosis in animal models of fatty liver disease, and for this reason it has been extensively studied for the treatment of NASH. These beneficial effects of OCA seem related to gut microbiota modulation. Indeed, in cirrhotic rats it has been demonstrated to improve dysbiosis and to reduce bacterial translocation [169]. The FLINT trial assessed the effect of $25 \mathrm{mg}$ of OCA given daily in adults with NASH: the administration of the drug was associated with weight loss and improved liver histology in terms of NAFLD activity score (NAS) and fibrosis [170]. The role of OCA for the treatment of NASH is currently under investigation in a large, randomized, phase III clinical trial (REGENERATE) [171]. Interim analysis of this study showed clinically significant histological improvement after administration of $25 \mathrm{mg}$ Obeticholic acid in patients with NASH [172].

\subsection{Currently under Investigation: Adsorbents, TLR-4 Signaling, FGF-19 and FGF-21 Signaling}

Adsorbents are poorly absorbable, adsorptive materials that are capable of binding gut-derived toxins and bacterial products, thus abrogating their inflow into the liver and systemic circulation with a consequent reduction in endotoxaemia [173]. Preliminary studies in rodents with NAFLD show a marked reduction in steatosis and hepatic inflammation: For example, Yaq-001, a synthetic activated carbon with the ability to selectively absorb intestinal-derived toxins (such as cytokines, hydrophobic bile acid and bacterial products) produced a significant reduction in ALT and hepatic TLR-4 expression in rodents with NAFLD [174]. Currently, clinical trials to assess therapeutic effect of Yaq-001 on humans are under investigation.

The TLR4 signaling, whose role in inflammation and fibrosis has extensively been described above, represents another promising target for the treatment of NAFLD: in particular JKB-121, a weak TLR4 receptor antagonist, has been studied in a phase II trial [175]. However, after 24 weeks of treatment, JKB-121 was found to not be superior to the placebo in reducing serum ALT or liver fat accumulation (measured with magnetic 
resonance imaging), and further studies are needed to address the role of TLR4 antagonists in the treatment of NAFLD.

As outlined before, bile acids mediate-through their ligand to FXR - the release of the enterokine FGF-19, which plays a key role in liver metabolism of lipid and glycogen. Hence, FGF-19 mimetics have been engineered despite their potentially carcinogenic effects. NGM282 is an engineered variant of human FGF19 that was found to retain the metabolic but not the tumorigenic effect of FGF-19 in preclinical models, and for this reason, it has been studied for the treatment of NASH. A phase II placebo-controlled trail of NGM282 for 12 weeks described a normalization of the hepatic fat content in $26-39 \%$ of patients with NASH $[176,177]$. The use of the drug, however, was associated with an increase in LDL-C levels.

\subsection{Bariatric Surgery}

In a prospective study conducted in 2015, bariatric surgery induced the disappearance of NASH from nearly $85 \%$ of patients and reduced the pathologic features of the disease after 1-year of follow-up [178]. This group of researchers analyzed then the same cohort after a 5-year follow-up in order to assess the long-term effects of bariatric surgery in patients with NASH: The resolution of NASH was observed in liver samples from $84 \%$ of patients [179].

This extraordinary result seems to once again be related not only to the metabolic effects of the bariatric surgery, but also to a great impact of these procedures on the gut homeostasis. Indeed, it is known, for example, that gastric bypass can favorably affect the gut microbiota by reducing the proportion of firmicutes, by remodeling the bile acid pool and by modulating the secretion of incretins $[180,181]$. Hence, this surgical procedure is able to affect most of the pathways of the gut-liver-axis.

\subsection{Fecal Microbiota Transplantation (FMT)}

FMT has been used successfully in the treatment of patients with refractory and recurrent Clostridium difficile, and it is increasingly emerging in the clinical practice as a promising therapeutic option for several other diseases, having the potential to restore an "healthy" microbiome [182]. As for the liver, several different preclinical studies and preliminary experience on humans have outlined the roles of FMT in cirrhosis and in the treatment of its complications [183-185]. Bajaj et al. conduced a phase 1 clinical safety trial of FMT in patients with decompensated cirrhosis on standard therapies (lactulose and rifaximin): FMT was well tolerated, and it was able to restore microbial diversity and function [186].

Moving from this evidence, a role of FMT in the treatment of NAFLD is emerging. Indeed, the restoration of a healthy intestinal microbiota has been demonstrated to interfere favorably in the pathogenesis of NAFLD in mouse models [187,188]. One preliminary experience on humans was conducted by Vrieze et al. in 2012: The authors demonstrated that the transfer of intestinal microbiota from lean donors could increase insulin sensitivity in individuals with metabolic syndrome [37].

However, no human studies have established the specific role of FMT in the treatment NAFLD at present. In a recent randomized controlled trial from Craven et al., allogenic FMT in patients with NAFLD did not improve insulin resistance nor did it significantly reduce hepatic fat fraction. However, as an interesting result, FMT showed the potential to reduce small intestinal permeability 6 weeks after the transplant [189].

In a double-blind randomized controlled proof-of-principle study of 2020 allogenic FMT using lean vegan donors in individuals with hepatic steatosis produced a modification of intestinal microbiota composition, which was associated with beneficial changes in plasma metabolites and markers of steatohepatitis [190].

Several other clinical trials exploring the role of FMT in the treatment of NAFLD are currently ongoing. 


\section{Conclusions}

NAFLD is nowadays the first cause of liver disease worldwide, affecting both adults and children, and in the near future it will emerge as the leading cause of end-stage liver disease. Indeed, its prevalence is rapidly increasing, and NAFLD is becoming a major public health concern: For this reason, great efforts have made in recent years to identify more the pathogenetic factors in more detail and to find new therapeutic targets. In fact, despite this great epidemiological burden, the pathophysiology of NAFLD is not entirely understood at present.

In the past decade, the enormous advances in understanding the biology of the gutliver axis have elucidated its role as one of the main actors in the development of NAFLD. Indeed, numerous evidence has implicated the intestinal microbiome in the development and progression of hepatocellular steatosis, inflammation and fibrosis seen in the context of NAFLD, as well as in hepatocarcinogenesis.

Once this close relationship is established, the microbiome has proposed as a useful tool to determine liver disease severity in NAFLD, and the risk of disease progression from NAFLD toward NASH and more severe fibrosis. In other words, gut microbiota is emerging as a potential non-invasive marker of disease-severity in NAFLD. In addition, gut microbiota has a role in the stratification of patient at high risk of developing HCC has proposed as well as a key role in the early diagnosis of hepatocarcinoma. Indeed, despite the great prevalence of NAFLD-related HCC, a structured surveillance program in absence of severe fibrosis remains to be established.

Moving towards its enormous diagnostic potential, the next step was to imagine the gut microbiome as a promising therapeutic target for NAFLD, whose treatment's options remain limited at present. In particular, preclinical experiences have established the great impact of microbiome-targeted therapies in mice ranging from antibiotics, probiotics, symbiotic to fecal microbiota transplantation (FMT), and studies conducted on humans so far seem to confirm this impact [Table 1]. Large, multicentric clinical trials exploring the metabolic effects of microbiome-targeted therapies in NAFLD and its complications (e.g., HCC) are currently ongoing.

\section{Key Points:}

1. NAFLD is the first cause of liver disease worldwide, but reliable non-invasive disease markers and efficacious therapeutic options are currently lacking.

2. Gut microbiota demonstrated its involvement in the pathogenesis of NAFLD spectrum diseases through several different mechanisms.

3. Due to its role in the pathogenesis and progression of NAFLD, gut microbiota may be considered as a potential noninvasive disease biomarker.

4. Modulation of the gut microbiota is currently under study as a promising therapeutic approach in NAFLD and its complications (e.g., HCC). 
Table 1. Summary of available human studies on treatments targeting the microbiome in NAFLD.

\begin{tabular}{|c|c|c|c|c|c|}
\hline & POPULATION & TREATMENT & STUDY DESIGN & & RESULTS \\
\hline \multicolumn{6}{|l|}{ Antibiotics } \\
\hline $\begin{array}{l}\text { Gangarapu et al., } \\
2015 \text { [126] }\end{array}$ & $\begin{array}{l}42 \text { adult patients with } \\
\text { biopsy-proven NAFLD } \\
\text { (steatosis, } n=15 \text {; } \\
\text { NASH, } n=27 \text { ) }\end{array}$ & $\begin{array}{l}\text { Rifaximin } \\
\text { (1200 mg/daily) for } \\
4 \text { weeks }\end{array}$ & $\begin{array}{l}\text { Prospective, open-label, } \\
\text { observational cohort } \\
\text { study }\end{array}$ & $\checkmark$ & $\begin{array}{l}\text { In the NASH group: } \\
\text { mild reduction in } \\
\text { BMI and significant } \\
\text { reduction ALT, AST, } \\
\text { GGT, LDL, ferritin, } \\
\text { plasma endotoxin } \\
\text { concentration and } \\
\text { IL-10 levels. } \\
\text { In the steatosis group: } \\
\text { significant reduction } \\
\text { in and ferritin. } \\
\text { Not significant effect } \\
\text { on serum levels of } \\
\text { TLR- } 4 \text {, IL-1, IL-6, } \\
\text { IL-12 or TNF- } \alpha \text { in } \\
\text { either group. }\end{array}$ \\
\hline
\end{tabular}

\begin{tabular}{llll}
\hline & $\begin{array}{l}\text { 15 patients with } \\
\text { biopsy-proven NASH } \\
\text { and elevated } \\
\text { aminotransferase } \\
\text { values }\end{array}$ & $\begin{array}{l}\text { Rifaximin 400 mg twice } \\
\text { daily for 6 weeks }\end{array}$ & Open-label pilot study \\
\hline 127$]$ & & \\
\hline
\end{tabular}

$\checkmark \quad$ No beneficial effect of biopsy-proven NASH aminotransferase daily for 6 weeks rifaximin in patients with NASH.

\begin{abstract}
Abdel-Razik A et al., 2018 [128]

50 patients with biopsy-proven NASH

Rifaximin $1100 \mathrm{mg} /$ day for 6 months $(n=25)$ vs. placebo $(n=25)$
\end{abstract}

Multicentric,

double-blind, randomized, placebo-controlled study
Significant reduction in homeostatic model assessment, ALT, AST, GGT, endotoxin, TLR-4, IL-6, TNF- $\alpha$, CK-18 and NAFLD-liver fat score (all $p<0.05$ ).

$\checkmark \quad$ No changes in the lipid profile.

$\checkmark \quad$ Mild non-statistically significant reduction of BMI.

Prebiotics

Daubioul et al., 2005 [132]
Patients with biopsy-proven NASH $(n=7)$
Oligofructose 16 g/day

(Raftilose P95 ${ }^{\circledR}$ ) vs.

placebo (maltodextrine) for 8 weeks
Randomized

double-blind crossover study
Significant reduction of AST ( $p<0.05$ vs. placebo) after 8 weeks, and insulin level after 4 weeks.

$\checkmark \quad$ Nonsignificant decrease of TG concentrations. 
Table 1. Cont.

\begin{tabular}{|c|c|c|c|c|c|}
\hline & POPULATION & TREATMENT & STUDY DESIGN & & RESULTS \\
\hline $\begin{array}{l}\text { Rocha R et al., } 2007 \\
\text { [133] }\end{array}$ & $\begin{array}{l}12 \text { patients with } \\
\text { NAFLD }\end{array}$ & $\begin{array}{l}10 \mathrm{~g} / \text { day of Psyllum } \\
\text { plantago husk } \\
\text { (Ispaghula husk) for } \\
3 \text { months }\end{array}$ & Open-label clinical trial & $\begin{array}{c}-12 \\
d \\
d\end{array}$ & $\begin{array}{l}100 \% \text { of patients } \\
\text { presented reduction } \\
\text { in BMI, waist } \\
\text { circumference and } \\
\text { insulin resistance } \\
\text { index. } \\
\text { Reduction of the } \\
\text { cholesterol levels in } \\
66.7 \% \text { of patients. } \\
75 \% \text { presented } \\
\text { normal liver enzymes } \\
\text { (AST, ALT, and GGT) }\end{array}$ \\
\hline
\end{tabular}

Ebrahimi-

Mameghani et al., 2014 [134]
60 obese adult patients with NAFLD
$400 \mathrm{mg} / \mathrm{d}$ of vitamin $\mathrm{E}$

plus four 300-mg tablets of Chorella vulgaris (ALGOMED) $(n=30)$ vs. placebo (400 $\mathrm{mg} / \mathrm{d}$ of vitamin $\mathrm{E}$ and four placebos/d)

$(n=30)$ for 8 weeks
Double-blind, randomized, placebo-controlled clinical trial $\checkmark \quad$ Weight, liver enzymes, FBS and lipid profile decreased significantly in both groups $(p<0.05)$, with statistically significant differences in the two groups $(p=0.01$, $p=0.04$ and $p=0.02$, respectively).
Akbarzadeh et al., 2015 [135]

75 overweight or obese adults with NAFLD
$10 \mathrm{~g}$ of psyllium (Plantago ovata) or $10 \mathrm{~g}$ of crushed wheat as placebo for 4 months
Single-blind, placebo-controlled, parallel, randomized clinical trial $\checkmark \quad$ Reduction in AST and ALT.

$\checkmark \quad$ No differences in BMI.
$16 \mathrm{~g} / \mathrm{d}$ prebiotic supplemented $(n=30)$ vs. isocaloric placebo $(n=30)$ for 24 weeks

Prebiotic group received powder

75 patients with

Javadi et al., 2017 [137]

\author{
60 adults $(\mathrm{BMI} \geq 25)$ \\ with confirmed \\ NAFLD
}

NAFLD divided into four groups (21 patients in the prebiotic group) (inulin HP: $10 \mathrm{~g} / \mathrm{d}$ ) and a placebo of probiotics (fat- and lactose-free milk capsules).
Double blind, placebo-controlled parallel group study

\section{$\checkmark \quad$ Currently ongoing \\ $\checkmark$ ClinicalTrials.gov (NCT02568605).}

Double-blind, placebo-controlled clinical trial $\checkmark \quad$ Reduction in AST $(p=0.045)$ and ALT $(p=0.041)$.

$\checkmark \quad$ No significant changes in the grade of fatty liver.
Loguercio et al.,2005 [139]
22 patients with biopsy-proven NAFLD
VSL\#3a for 3 months $\checkmark \quad$ Significant improvement in ALT and AST.

$\checkmark \quad$ Significant reduction in markers of oxidation (malondialdehyde and 4-hydroynonenal) and in levels of S-nitrosothiol. 
Table 1. Cont.

\begin{tabular}{lll}
\hline & & \\
Aller et al., 2011 & $\begin{array}{l}\text { One tablet per day of } \\
\text { probiotic mix (500 } \\
\text { million CFU L. } \\
\text { biopsy-proven NAFLD } \\
\text { bulgaricus and S. } \\
\text { thermophiles) or } \\
\text { placebo (120 mg of } \\
\text { starch) for 3 months }\end{array}$
\end{tabular}

Double-blind, randomized clinical trial $\checkmark \quad$ Significant reduction in AST, ALT and GGT levels.

$\checkmark$ Any effects on glucose, TC, LDL, HDL, TG, insulin, HOMA-IR, IL-6 or TNF- $\alpha$ levels.
[141]
20 obese children (age $10.7 \pm 2.1$ years) with persisting hypertransaminasemia and ultrasound evidence of fatty liver
Oral Lactobacillus

Gorbach-Goldin 12

billion CFU/d $(n=10)$, or placebo $(n=10)$ for 8 weeks
Double-blind, placebo-controlled pilot study

Significant decrease in ALT and in peptidoglycanpolysaccharide (average variation vs. placebo $p=0.03$ for each).

$\checkmark \quad$ No significant differences in BMI, visceral fat, TNF- $\alpha$ levels or hepatorenal ultrasonographic ratio.

Wong et al., 2013

[142]

20 adults with histology-proven $\mathrm{NASH}$
"Usual care" $(n=10)$ or one sachet of Lepicol b.i.d. $(n=10)$ for

Randomized controlled trial
Reduction in AST levels and intrahepatic triglycerides (IHTG). 6 months alterations in TG, BMI, ALT, fasting glucose, TC, HDL, LDL, hepatic TG or liver stiffness.
Shavakhi et al., 2013 [143]
64 adults with

biopsy-confirmed

NASH and persistent elevation of ALT
Two tablets of metformin $500 \mathrm{mg}$ and either probiotic supplement daily (Protexin two tablets per day) (group I, $n=31$ ) or placebo (group II, $n=32$ ) for 6 months
Randomized clinical trial $\checkmark \quad$ Significant reduction in ALT, AST and ultrasound grading of NASH in group I; reduction in AST and ultrasound grading of NASH in group II.

$\checkmark$ Significant reduction in BMI, TG and TC levels ( $p \leq 0.02$ for all) in both groups.
72 patients with

Nabavi et al., 2014 [144]
NAFLD (33 males and 39 females) aged 23 to 63 year old
$300 \mathrm{~g} / \mathrm{d}$ of conventional yogurt $(n=36)$ or yogurt enriched with $B$ lactis $\mathrm{Bb} 12$ and $\mathrm{L}$ acidophilus La5 $(n=36)$ for 8 weeks
Double-blind, randomized, controlled clinical trial
Significant reduction in ALT, AST, TC and LDL serum levels ( $p<0.05$ for all).

$\checkmark \quad$ No significant changes in levels of serum glucose, TG, or HDL in each group. 
Table 1. Cont.

$\begin{array}{ll}\text { Alisi et al., 2014 } & \begin{array}{l}44 \text { obese children } \\ \text { with histologically } \\ \text { d145] }\end{array} \\ \text { diagnosed NAFLD }\end{array}$

Alisi et al., 2014 with histologically diagnosed NAFLD
VSL\#3a (1 sachet/d for patients aged $<10$ year or 2 sachets / $\mathrm{d}$ for patients aged $>10$ year) $(n=22)$ vs. placebo ( $n=22)$ for 4 months

Double-blind, randomized clinical trial

Double-blind randomized clinical trial
Risk of severe steatosis was significantly lower $(p<0.001)$.

$\checkmark \quad$ Significant reduction in BMI $(p<0.001)$.

$\checkmark$ Trend towards a reduction in GLP-1.

$\checkmark \quad$ Mo significant changes were observed for TG, HOMA-IR or ALT levels.
Sepideh et al., $2016 \quad 42$ patients with [146]
Two capsules/day probiotic or placebo for 8 weeks
Significant decrease in insulin, insulin resistance, TNF- $\alpha$ and IL-6.

Multi-strain probiotic "Symbiter" (concentrated biomass of 14 probiotic bacteria

Kobyliak N et al., 2018 [147]

58 type 2 diabetes patients with NAFLD genera Bifidobacterium, Lactobacillus,

Lactococcus, Propionibacterium) $(n=30)$ vs. placebo $(n=28)$ for 8 weeks
Double-blind, single center, randomized clinical trial $\checkmark \quad$ Significant reduction in fatty liver index (FLI), aminotransferase activity, and in the TNF- $\alpha$ and IL-6 levels.
Duseja A et al., 201939 liver biopsy-proven [148]

39 liver biopsy-proven
patients with NAFLD
Lifestyle modifications plus an oral multistrain probiotic ( 675 billion bacteria daily) $(n=19)$ or identical placebo $(n=20)$ for 1 year
Double-blind, randomized clinical trial
In comparison to baseline, hepatocyte ballooning ( $p=0.036)$, lobular inflammation $(p=0.003)$ and NAS score $(p=0.007)$ improved significantly in the probiotic group.

$\checkmark$ Compared with placebo, the NAS score improved significantly in the probiotic group $(p=0.004)$, along with improvements in hepatocyte ballooning ( $p=0.05)$ and hepatic fibrosis $(p=0.018)$.

$\checkmark$ Significant improvement in levels of ALT $(p=0.046)$, leptin $(p=0.006)$, TNF- $\alpha$ $(p=0.016)$ and endotoxins $(p=0.017)$. 
Table 1. Cont.

\begin{tabular}{|c|c|c|}
\hline \multicolumn{3}{|l|}{ Symbiotics } \\
\hline $\begin{array}{l}\text { Malaguarnera et al., } \\
2012 \text { [151] }\end{array}$ & $\begin{array}{l}66 \text { patients with } \\
\text { histologically } \\
\text { diagnosed NASH }\end{array}$ & $\begin{array}{l}24 \text { weeks of a synbiotic } \\
\text { (Bifidobacterium } \\
\text { longum plus a prebiotic } \\
\text { [fructooligosaccharides]) } \\
\text { and lifestyle } \\
\text { modification (i.e., diet } \\
\text { and exercise) versus } \\
\text { lifestyle modification } \\
\text { alone }\end{array}$ \\
\hline
\end{tabular}

$\checkmark$ Significantly lower levels of AST, LDL, TNF- $\alpha$, C-reactive protein (CRP), HOMA index and

\section{Randomized controlled serum endotoxin.} trial Histologic improvement (decreased hepatocellular injury, inflammation and steatosis) $(p<0.05)$.
Eslamparast et al., 2014 [152]

52 patients with NAFLD
Daily 2 synbiotic capsules (each one containing seven probiotic strains and fructooligosaccharides) vs. 2 placebo capsules for 28 weeks
Randomized, double-blind, placebo-controlled clinical trial
Significant reduction in liver enzymes (ALT, AST, GGT), inflammatory markers (CRP, TNF- $\alpha$ and total nuclear factor $\mathrm{k}-\mathrm{B}$ p65).

$\checkmark \quad$ Reduction of $2.99 \mathrm{kPa}$ in the hepatic fibrosis score as determined by transient elastography $(p<0.001)$.
Ferolla et al., 2016 [153]

50 biopsy-proven NASH patients
Lactobacillus reuteri with guar gum and inulin for 3 months and healthy balanced nutritional counseling vs. nutritional counseling alone
Randomized, controlled clinical trial $\checkmark \quad$ Symbiotic group presented a reduction in steatosis, lost weight, diminished BMI and waist circumference measurement.

$\checkmark$ Symbiotic did not improve intestinal permeability or LPS levels. $\checkmark \quad$ In the symbiotic group, ultrasound grade decreased significantly compared to baseline $(p<0.005)$.
$500 \mathrm{mg}$ capsule (containing seven species of probiotic bacteria and fructooligosaccharides) daily for 8 weeks
Randomized, double-blind, placebo-controlled clinical trial ultrasound-diagnosed NAFLD
Asgharian et al., 2016 [154] or a placebo capsule

80 patients with
No significant differences in CRP, ALT or AST levels were observed between groups (adjusted for energy intake). 
Table 1. Cont.

Asgharian et al., 2017 [155]

80 patients with ultrasound-diagnosed NAFLD
Symbiotic in form of a

$500 \mathrm{mg}$ capsule

(containing seven

species of probiotic

bacteria and

fructooligosaccharides)

or a placebo capsule

daily for 8 weeks
Randomized,

double-blind,

placebo-controlled

clinical trial

$\checkmark \quad$ Significant reduction in weight $(p=0.001)$, body fat $(p=0.02)$ and total cholesterol $(p=0.04)$.

$\checkmark \quad$ TC and LDL $(p=0.04$ and $p=0.001$, respectively) were significantly increased in the placebo group.

$\checkmark$ TG, HDL and FBS levels remained statistically unchanged in both groups.

Significant reductions

50 lean patients with Mofidi et al., $2017 \quad$ NAFLD (patients had [156] steatosis and elevated ALT)
Synbiotic supplementation vs. placebo for 28 weeks
Randomized, double-blind, placebo-controlled, clinical trial in fibrosis and hepatic steatosis.

$\checkmark \quad$ FBS, TG levels and markers of inflammation.

Synbiotic (combination

of

fructooligosaccharides;

$4 \mathrm{~g} /$ day and

Scorletti

et al.-INSYTE

study 2020 [158]
Bifidobacterium animalis subsp. lactis BB-12 at a minimum of 10 billion CFU/day) ( $n$

$=55)$ or placebo $(n$

= 49) for 1 year
Randomized

double-blind

placebo-controlled trial
Synbiotic administration altered the fecal microbiome but did not reduce liver fat content or markers of liver fibrosis

Metformin

Haukeland et al., 2009 [164]
48 adult patients with biopsy-confirmed NAFLD
Metformin $2500 \mathrm{mg} / \mathrm{d}$

(3000 $\mathrm{mg}$ if weight $>$ $90 \mathrm{~kg})(n=24) \mathrm{vs}$. placebo $(n=24)$ for 6 months
Randomized double-blind, placebo-controlled trial
No significant differences were observed for changes in liver steatosis (assessed either histologically or by CT), NAS-score, liver transaminases or on markers of insulin resistance or inflammation.

$\checkmark$ In contrast, beneficial effects of metformin were observed on changes in body weight $(p<0.001)$, serum levels of cholesterol $(p=0.004)$, LDL $(p<0.001)$, glucose $(p=0.032)$ and on HbA1c $(p=0.020)$. 
Table 1. Cont.

\begin{tabular}{|c|c|c|c|c|c|}
\hline $\begin{array}{l}\text { Omer et al., } 2010 \\
\text { [165] }\end{array}$ & $\begin{array}{l}64 \text { adults with type } 2 \\
\text { diabetes or impaired } \\
\text { glucose tolerance and } \\
\text { biopsy-confirmed } \\
\text { NAFLD divided into } \\
\text { three groups }\end{array}$ & $\begin{array}{l}\text { Group } 1(n=22) \\
\text { received metformin } \\
1700 \mathrm{mg} / \text { day for } \\
12 \text { months }\end{array}$ & $\begin{array}{l}\text { Open-label, } \\
\text { randomized, } \\
\text { single-center study }\end{array}$ & $\checkmark$ & $\begin{array}{l}\text { No significant } \\
\text { decrease in serum } \\
\text { transaminase and } \\
\text { GGT levels, } \\
\text { homeostasis model } \\
\text { assessment-insulin } \\
\text { resistance and NAS } \\
\text { on follow-up biopsy. }\end{array}$ \\
\hline $\begin{array}{l}\text { Razavizade et al., } \\
2013 \text { [166] }\end{array}$ & $\begin{array}{l}80 \text { adults with NAFLD } \\
\text { assessed via } \\
\text { ultrasonography and } \\
\text { predictive formula } \\
\text { divided into two } \\
\text { groups }\end{array}$ & $\begin{array}{l}\text { Group } 1 \text { received } \\
\text { Metformin } 1000 \mathrm{mg} / \mathrm{d} \\
(n=40) \text { for } 4 \text { months }\end{array}$ & $\begin{array}{l}\text { Double-blind clinical } \\
\text { trial }\end{array}$ & $\checkmark$ & $\begin{array}{l}\text { Significantly } \\
\text { decreased serum } \\
\text { levels of liver } \\
\text { function tests, FBS, } \\
\text { TC, LDL, HOMA-IR, } \\
\text { LFC and increased } \\
\text { serum level of HDL. }\end{array}$ \\
\hline $\begin{array}{l}\text { Rana et al., } 2016 \\
\text { [167] }\end{array}$ & $\begin{array}{l}98 \text { patients with } \\
\text { ultrasound diagnosed } \\
\text { NAFLD divided into } \\
\text { three groups }\end{array}$ & $\begin{array}{l}\text { Group } 1(n=31) \\
\text { received Metformin } \\
\text { along with dietary } \\
\text { intervention and } \\
\text { lifestyle modification } \\
\text { for } 24 \text { weeks }\end{array}$ & Randomized trial & $\checkmark$ & $\begin{array}{l}\text { Metformin was not } \\
\text { effective as add on } \\
\text { therapy for NAFLD. }\end{array}$ \\
\hline $\begin{array}{l}\text { Anushiravani et al., } \\
2019 \text { [168] }\end{array}$ & $\begin{array}{l}150 \text { consecutive } \\
\text { patients with NAFLD } \\
\text { who were assigned to } \\
\text { five groups }\end{array}$ & $\begin{array}{l}\text { Group } 2(n=30) \\
\text { received Metformin } \\
500 \mathrm{mg} / \text { day for } \\
3 \text { months }\end{array}$ & $\begin{array}{l}\text { Double-blinded, } \\
\text { randomized } \\
\text { placebo-controlled trial }\end{array}$ & $\checkmark$ & $\begin{array}{l}\text { No significant benefit } \\
\text { of Metformin } \\
\text { administration. }\end{array}$ \\
\hline \multicolumn{6}{|c|}{ Bile acid homeostasis targeting } \\
\hline $\begin{array}{l}\text { Neuschwander- } \\
\text { Tetri et al., 2015- } \\
\text { FLINT trial [170] }\end{array}$ & $\begin{array}{l}283 \text { patients with } \\
\text { non-cirrhotic NASH }\end{array}$ & $\begin{array}{l}\text { Obeticholic acid given } \\
\text { orally ( } 25 \mathrm{mg} \text { daily) } \\
(n=141) \text { or placebo } \\
(n=142) \text { for } 72 \text { weeks }\end{array}$ & $\begin{array}{l}\text { Multicentre, } \\
\text { double-blind, } \\
\text { placebo-controlled, } \\
\text { parallel group, } \\
\text { randomized clinical } \\
\text { trial }\end{array}$ & $\checkmark$ & $\begin{array}{l}\text { OCA significantly } \\
\text { improved the } \\
\text { primary histological } \\
\text { outcome (i.e., } \\
\text { NAFLD activity } \\
\text { score) and reduced } \\
\text { liver fibrosis } \\
\text { compared with } \\
\text { placebo. } \\
\text { Several safety issues, } \\
\text { including: (a) } \\
\text { pruritus; (b) } \\
\text { dyslipidaemia, with } \\
\text { increased total and } \\
\text { LDL cholesterol and } \\
\text { mild, but significant, } \\
\text { reductions in HDL; } \\
\text { (c) concerns } \\
\text { regarding the } \\
\text { carcinogenic } \\
\text { potential of increased } \\
\text { circulating FGF19. }\end{array}$ \\
\hline
\end{tabular}


Table 1. Cont.

\begin{tabular}{|c|c|c|c|c|}
\hline $\begin{array}{l}\text { REGENERATE trial } \\
{[171,172]}\end{array}$ & $\begin{array}{l}\sim 2400 \text { patients with } \\
\text { histologic evidence of } \\
\text { NASH (including } \\
\sim 2100 \text { patients with } \\
\text { stage } 2 \text { or } 3 \text { liver } \\
\text { fibrosis) }\end{array}$ & $\begin{array}{l}\text { Patients are } \\
\text { randomized 1:1:1 to } \\
\text { receive } 10 \mathrm{mg} \text { OCA, } \\
25 \mathrm{mg} \text { OCA or placebo }\end{array}$ & $\begin{array}{l}\text { Phase 3, double-blind, } \\
\text { randomized, long-term, } \\
\text { placebo-controlled, } \\
\text { multicenter study }\end{array}$ & $\begin{array}{l}\text { Currently } \\
\text { ongoing-Interim } \\
\text { analysis showed } \\
\text { clinically significant } \\
\text { histological } \\
\text { improvement after } \\
\text { Obeticholic acid } \\
25 \text { mg administration } \\
\text { in patients with } \\
\text { NASH. }\end{array}$ \\
\hline
\end{tabular}

\section{Adsorbents}

\begin{tabular}{|c|c|c|c|c|c|}
\hline $\begin{array}{l}\text { Safety and } \\
\text { tolerability of } \\
\text { Yaq-001 in patients } \\
\text { with NASH }\end{array}$ & 70 patients with $\mathrm{NASH}$ & $\begin{array}{l}\text { Standard medical } \\
\text { treatment }+ \text { Yaq-001 (8 } \\
\text { g/day) }(n=35) \text { vs. } \\
\text { standard medical } \\
\text { treatment }+ \\
\text { placebo-control } \\
\text { (placebo for } 8 \mathrm{~g} \text { of } \\
\text { Yaq-001/day) }(n=35) \\
\text { for } 48 \text { weeks }\end{array}$ & $\begin{array}{l}\text { Multicentre, } \\
\text { randomized, double } \\
\text { blinded, } \\
\text { placebo-controlled trial }\end{array}$ & $\begin{array}{l}\checkmark \\
\checkmark\end{array}$ & $\begin{array}{l}\text { Currently ongoing } \\
\text { clinicaltrials.gov } \\
\text { (NCT03962608). }\end{array}$ \\
\hline \multicolumn{6}{|l|}{ TLR-4 signaling } \\
\hline $\begin{array}{l}\text { Diehl et al., } 2018 \\
\text { [175] }\end{array}$ & $\begin{array}{l}65 \text { patients with } \\
\text { biopsy-proven NASH } \\
\text { with a NAS >/=4, } \\
>/=6 \% \text { liver fat content } \\
\text { (LFC) by MRI and } \\
\text { elevated ALT }\end{array}$ & $\begin{array}{l}\text { JKB-121 } 5 \mathrm{mg}, 10 \mathrm{mg} \text { or } \\
\text { placebo twice daily for } \\
24 \text { weeks }\end{array}$ & $\begin{array}{l}\text { Multicenter, } \\
\text { double-blind, } \\
\text { randomized, } \\
\text { placebo-controlled trial }\end{array}$ & $\checkmark$ & $\begin{array}{l}\text { Not superior to } \\
\text { placebo in reducing } \\
\text { LFC (determined by } \\
\text { MRI) and ALT. } \\
\text { Notable } \\
\text { improvement in LFC, } \\
\text { ALT and FIB-4 in the } \\
\text { placebo group. }\end{array}$ \\
\hline
\end{tabular}

FGF-19 signaling

82 adults with

Harrison et al., 2018 biopsy-confirmed

[176] groups

Daily subcutaneous injections with $3 \mathrm{mg}$ NGM282 $(n=27), 6 \mathrm{mg}$ NGM282 $(n=28)$ or placebo $(n=27)$ for 12 weeks
Phase II, double-blind, placebo-controlled, randomized controlled trial

Subcutaneous NGM282

(1 mg, $n=24 ; 3 \mathrm{mg}$, $n=19)$ once daily for Open-label study $\checkmark \quad$ Rapid and significant reductions in LFC with an acceptable safety profile.

$\checkmark$ Increase in LDL levels.

\section{Harrison et al., 201943 patients with [177] \\ biopsy-confirmed $\mathrm{NASH}$}

12 weeks

\section{$\checkmark \quad$ NGM282}

significantly reduced NAS with $p<0.001$ both in the $1 \mathrm{mg}$ and in the $3 \mathrm{mg}$ group, and fibrosis scores $(p=0.035$ in the $3 \mathrm{mg}$ group).

$\checkmark \quad$ Improvement in noninvasive imaging (LFC), serum markers (AST, ALT and fibrogenesis biomarkers) and enhanced liver fibrosis score (ELF). 
Table 1. Cont.

\begin{tabular}{|c|c|c|c|c|c|}
\hline \multicolumn{6}{|l|}{ Bariatric surgery } \\
\hline $\begin{array}{l}\text { Lassailly et al., } 2015 \\
{[178,179]}\end{array}$ & $\begin{array}{l}180 \text { morbidly obese } \\
\text { patients with } \\
\text { biopsy-proven NASH }\end{array}$ & $\begin{array}{l}\text { Bariatric surgery } \\
\text { (gastric banding; } \\
\text { gastric bypass; Roux- } \\
\text { en-Y-Gastric-bypass; } \\
\text { sleeve gastrectomy) }\end{array}$ & Prospective study & $\checkmark$ & $\begin{array}{l}\text { Bariatric surgery } \\
\text { induced the } \\
\text { disappearance of } \\
\text { NASH from nearly } \\
85 \% \text { of patients and } \\
\text { reduced the } \\
\text { pathologic features of } \\
\text { the disease after } \\
1 \text { year and after } \\
5 \text { years of follow-up. }\end{array}$ \\
\hline \multicolumn{6}{|c|}{ Fecal Microbial Transplantation } \\
\hline $\begin{array}{l}\text { Craven et al., } 2020 \\
\text { [189] }\end{array}$ & $\begin{array}{l}21 \text { patients with } \\
\text { NAFLD }\end{array}$ & $\begin{array}{l}\text { Allogenic }(n=15) \text { or } \\
\text { autologous }(n=6) \text { FMT } \\
\text { delivered by using an } \\
\text { endoscope to the distal } \\
\text { duodenum }\end{array}$ & $\begin{array}{l}\text { Randomized controlled } \\
\text { trial }\end{array}$ & $\checkmark$ & $\begin{array}{l}\text { FMT did not improve } \\
\text { IR as measured by } \\
\text { HOMA-IR or hepatic } \\
\text { proton density fat } \\
\text { fraction (PDFF) but } \\
\text { did have the } \\
\text { potential to reduce } \\
\text { small intestinal } \\
\text { permeability in } \\
\text { patients with } \\
\text { NAFLD. }\end{array}$ \\
\hline $\begin{array}{l}\text { Witjes et al., } 2020 \\
\text { [190] }\end{array}$ & $\begin{array}{l}21 \text { individuals with } \\
\text { hepatic steatosis on } \\
\text { ultrasound }\end{array}$ & $\begin{array}{l}\text { Lean vegan donor } \\
\text { (allogenic } n=10 \text { ) or } \\
\text { own (autologous } \\
n=11 \text { ) FMT; both were } \\
\text { performed three times } \\
\text { at 8-week intervals }\end{array}$ & $\begin{array}{l}\text { Double-blind, } \\
\text { randomized, controlled, } \\
\text { proof-of-principle } \\
\text { study }\end{array}$ & $\checkmark$ & $\begin{array}{l}\text { Allogenic FMT using } \\
\text { lean vegan donors in } \\
\text { individuals with } \\
\text { hepatic steatosis } \\
\text { shows an effect on } \\
\text { intestinal microbiota } \\
\text { composition, which } \\
\text { is associated with } \\
\text { beneficial changes in } \\
\text { plasma metabolites } \\
\text { and markers of } \\
\text { steatohepatitis. }\end{array}$ \\
\hline
\end{tabular}

Author Contributions: Conceptualization, F.F. and L.M.; methodology, L.M.; investigation, F.F.; writing-original draft preparation, F.F.; writing—review and editing, A.L. and L.M.; supervision, L.M., A.G. (Antonio Grieco) and A.G. (Antonio Gasbarrini). All authors have read and agreed to the published version of the manuscript.

Funding: This research received no external funding.

Acknowledgments: We would like to thank Franziska M. Lohmeyer, Fondazione Policlinico Universitario A. Gemelli IRCCS, for her support revising our manuscript.

Conflicts of Interest: All authors declare no conflict of interests for this article. 


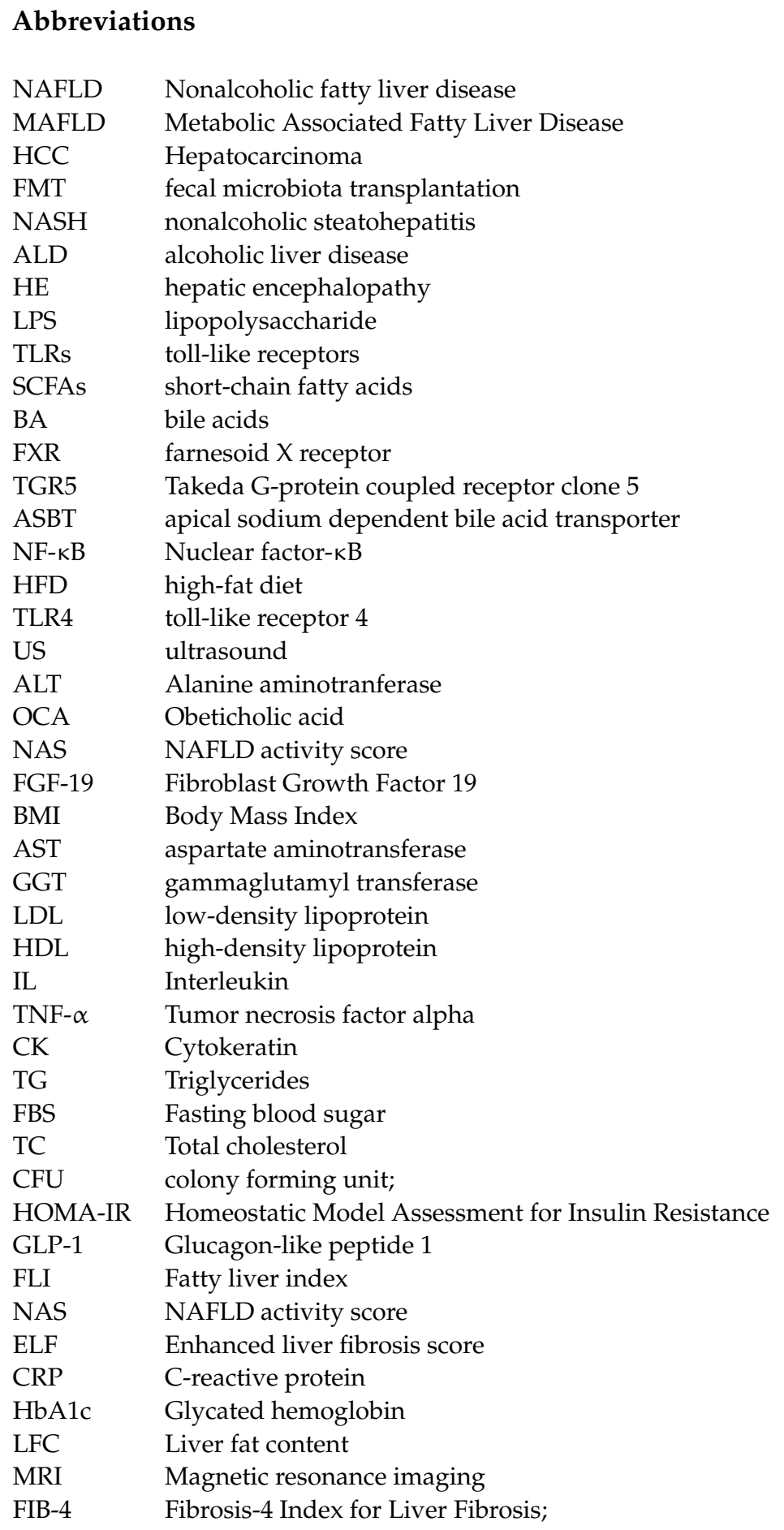

\section{References}

1. The Human Microbiome Project Consortium. Structure, function and diversity of the healthy human microbiome. Nature 2012, 486, 207-214. [CrossRef]

2. Qin, J.; Li, R.; Raes, J.; Arumugam, M.; Burgdorf, K.S.; Manichanh, C.; Nielsen, T.; Pons, N.; Levenez, F.; Yamada, T.; et al. A human gut microbial gene catalogue established by metagenomic sequencing. Nature 2010, 464, 59-65. [CrossRef]

3. Jandhyala, S.M.; Talukdar, R.; Subramanyam, C.; Vuyyuru, H.; Sasikala, M.; Reddy, D.N. Role of the normal gut microbiota. World J. Gastroenterol. 2015, 21, 8787-8803. [CrossRef]

4. Festi, D.; Schiumerini, R.; Birtolo, C.; Marzi, L.; Montrone, L.; Scaioli, E.; Di Biase, A.R.; Colecchia, A. Gut microbiota and its pathophysiology in health and disease. Dig. Dis. 2011, 29, 518-524. [CrossRef] [PubMed]

5. Sekirov, I.; Russel, S.L.; Antunes, C.M.; Finlay, B.B. Gut microbiota in health and disease. Physiol. Rev. 2010, 90, 859-904. [CrossRef] 
6. Lozupone, C.A.; Stombaugh, J.I.; Gordon, J.I.; Jansson, J.; Knight, R. Diversity, stability and resilience of the human gut microbiota. Nat. Cell Biol. 2012, 489, 220-230. [CrossRef] [PubMed]

7. Benson, A.K.; Kelly, S.A.; Legge, R.; Ma, F.; Low, S.J.; Kim, J.; Zhang, M.; Oh, P.L.; Nehrenberg, D.; Hua, K.; et al. Individuality in gut microbiota composition is a complex polygenic trait shaped by multiple environmental and host genetic factors. Proc. Natl. Acad. Sci. USA 2010, 107, 18933. [CrossRef]

8. Schnabl, B.; Brenner, D. Interactions Between the Intestinal Microbiome and Liver Diseases. Gastroenterology 2014, 146, 1513-1524. [CrossRef]

9. Betrapally, N.S.; Gillevet, P.M.; Bajaj, J.S. Gut microbiome and liver disease. Transl. Res. 2017, 179, 49-59. [CrossRef]

10. Shen, T.C.D.; Pyrsopoulos, N.; Rustgi, V.K. Microbiota and the Liver. Liver Transplant. 2018, 24, 539-550. [CrossRef] [PubMed]

11. Björkholm, B.; Bok, C.M.; Lundin, A.; Rafter, J.; Hibberd, M.L.; Pettersson, S. Intestinal Microbiota Regulate Xenobiotic Metabolism in the Liver. PLoS ONE 2009, 4, e6958. [CrossRef] [PubMed]

12. Mazagova, M.; Wang, L.; Anfora, A.T.; Wissmueller, M.; Lesley, S.A.; Miyamoto, Y.; Eckmann, L.; Dhungana, S.; Pathmasiri, W.; Sumner, S.; et al. Commensal microbiota is hepatoprotective and prevents liver fibrosis in mice. FASEB J. 2014, 29, 1043-1055. [CrossRef]

13. Mutlu, E.A.; Gillevet, P.M.; Rangwala, H.; Sikaroodi, M.; Naqvi, A.; Engen, P.A.; Kwasny, M.; Lau, C.K.; Keshavarzian, A. Colonic microbiome is altered in alcoholism. Am. J. Physiol. Gastrointest. Liver Physiol. 2012, 302, G966-G978. [CrossRef] [PubMed]

14. Seki, E.; Schnabl, B. Role of innate immunity and the microbiota in liver fibrosis: Crosstalk between the liver and gut. J. Physiol. 2012, 590, 447-458. [CrossRef]

15. Qin, N.; Yang, F.; Li, A.; Prifti, E.; Chen, Y.; Shao, L.; Guo, J.; Le Chatelier, E.; Yao, J.; Wu, L.; et al. Alterations of the human gut microbiome in liver cirrhosis. Nature 2014, 513, 59-64. [CrossRef]

16. Bajaj, J.S.; Heuman, D.M.; Hylemon, P.B.; Sanyal, A.J.; White, M.B.; Monteith, P.; Noble, N.A.; Unser, A.B.; Daita, K.; Fisher, A.R.; et al. Altered profile of human gut microbiome is associated with cirrhosis and its complications. J. Hepatol. 2014, 60, 940-947. [CrossRef] [PubMed]

17. Gomez-Hurtado, I.; Such, J.; Sanz, Y.; Francés, R. Gut microbiota-related complications in cirrhosis. World J. Gastroenterol. 2014, 20, 15624-15631. [CrossRef]

18. Acharya, C.; Sahingur, S.E.; Bajaj, J.S. Microbiota, cirrhosis, and the emerging oral-gut-liver axis. JCI Insight 2017, 2, e94416. [CrossRef]

19. Arab, J.P.; Martin-Mateos, R.; Shah, V.H. Gut-liver axis, cirrhosis and portal hypertension: The chicken and the egg. Hepatol. Int. 2017, 12, 24-33. [CrossRef]

20. Younossi, Z.; Anstee, Q.M.; Marietti, M.; Hardy, T.; Henry, L.; Eslam, M.; George, J.; Bugianesi, E. Global burden of NAFLD and NASH: Trends, predictions, risk factors and prevention. Nat. Rev. Gastroenterol. Hepatol. 2017, 15, 11-20. [CrossRef]

21. Hardy, T.; Oakley, F.; Anstee, Q.M.; Day, C.P. Nonalcoholic fatty liver disease: Pathogenesis and disease spectrum. Annu. Rev. Pathol. 2016, 11, 451-496. [CrossRef]

22. Eslam, M.; Sanyal, A.J.; George, J.; International Consensus Panel. MAFLD: A Consensus-Driven Proposed Nomenclature for Metabolic Associated Fatty Liver Disease. Gastroenterology 2020, 158, 1999-2014.e1. [CrossRef] [PubMed]

23. Day, C.P.; James, O.F. Steatohepatitis: A tale of two 'hits'? Gastroenterology 1998, 114, 842-845. [CrossRef]

24. Buzzetti, E.; Pinzani, M.; Tsochatzis, E.A. The multiple-hit pathogenesis of non-alcoholic fatty liver disease (NAFLD). Metabolism 2016, 65, 1038-1048. [CrossRef]

25. Machado, M.V.; Cortez-Pinto, H. Diet, Microbiota, Obesity, and NAFLD: A Dangerous Quartet. Int. J. Mol. Sci. 2016, 17, 481. [CrossRef]

26. Leung, C.; Rivera, L.; Furness, J.B.; Angus, P.W. The role of the gut microbiota in NAFLD. Nat. Rev. Gastroenterol. Hepatol. 2016, 13, 412-425. [CrossRef]

27. Safari, Z.; Gérard, P. The links between the gut microbiome and non-alcoholic fatty liver disease (NAFLD). Cell. Mol. Life Sci. 2019, 76, 1541-1558. [CrossRef] [PubMed]

28. Kolodziejczyk, A.; Zheng, D.; Shibolet, O.; Elinav, E. The role of the microbiome in NAFLD and NASH. EMBO Mol. Med. 2018, 11, e9302. [CrossRef] [PubMed]

29. Wong, V.W.-S.; Tse, C.-H.; Lam, T.T.-Y.; Wong, G.L.-H.; Chim, A.M.-L.; Chu, W.; Yeung, D.K.-W.; Law, P.T.-W.; Kwan, H.-S.; Yu, J.; et al. Molecular Characterization of the Fecal Microbiota in Patients with Nonalcoholic Steatohepatitis-A Longitudinal Study. PLoS ONE 2013, 8, e62885. [CrossRef] [PubMed]

30. Raman, M.; Ahmed, I.; Gillevet, P.M.; Probert, C.S.; Ratcliffe, N.M.; Smith, S.; Greenwood, R.; Sikaroodi, M.; Lam, V.; Crotty, P.; et al. Fecal Microbiome and Volatile Organic Compound Metabolome in Obese Humans with Nonalcoholic Fatty Liver Disease. Clin. Gastroenterol. Hepatol. 2013, 11, 868-875. [CrossRef] [PubMed]

31. Mouzaki, M.; Comelli, E.M.; Arendt, B.M.; Bonengel, J.; Fung, S.K.; Fischer, S.E.; McGilvray, I.D.; Allard, J.P. Intestinal mi-crobiota in patients with nonalcoholic fatty liver disease. Hepatology 2013, 58, 120-127. [CrossRef]

32. Zhu, L.; Baker, S.S.; Gill, C.; Liu, W.; Alkhouri, R.; Baker, R.D.; Gill, S.R. Characterization of gut microbiomes in nonalcoholic steatohepatitis (NASH) patients: A connection between endogenous alcohol and NASH. Hepatology 2013, 57, 601-609. [CrossRef]

33. Wieland, A.; Frank, D.N.; Harnke, B.; Bambha, K. Systematic review: Microbial dysbiosis and nonalcoholic fatty liver disease. Aliment. Pharmacol. Ther. 2015, 42, 1051-1063. [CrossRef] 
34. Qian, M.; Hu, H.; Yao, Y.; Zhao, D.; Wang, S.; Pan, C.; Duan, X.; Gao, Y.; Liu, J.; Zhang, Y.; et al. Coordinated changes of gut microbiome and lipidome differentiates nonalcoholic steatohepatitis (NASH) from isolated steatosis. Liver Int. 2019, 40, 622-637. [CrossRef] [PubMed]

35. Schwimmer, J.B.; Johnson, J.S.; Angeles, J.E.; Behling, C.; Belt, P.H.; Borecki, I.; Bross, C.; Durelle, J.; Goyal, N.P.; Hamilton, G.; et al. Microbiome Signatures Associated with Steatohepatitis and Moderate to Severe Fibrosis in Children with Nonalcoholic Fatty Liver Disease. Gastroenterology 2019, 157, 1109-1122. [CrossRef] [PubMed]

36. Le Roy, T.; Llopis, M.; Lepage, P.; Bruneau, A.; Rabot, S.; Bevilacqua, C.; Martin, P.; Philippe, C.; Walker, F.; Bado, A.; et al. Intestinal microbiota determines development of non-alcoholic fatty liver disease in mice. Gut 2013, 62, 1787-1794. [CrossRef]

37. Vrieze, A.; van Nood, E.; Holleman, F.; Salojärvi, J.; Kootte, R.S.; Bartelsman, J.F.; Dallinga-Thie, G.M.; Ackermans, M.T.; Serlie, M.J.; Oozeer, R.; et al. Transfer of Intestinal Microbiota from Lean Donors Increases Insulin Sensitivity in Individuals With Metabolic Syndrome. Gastroenterology 2012, 143, 913-916.e7. [CrossRef]

38. Ghetti, F.D.F.; Oliveira, D.G.; de Oliveira, J.M.; Ferreira, L.E.V.V.D.C.; Cesar, D.E.; Moreira, A.P.B. Influence of gut microbiota on the development and progression of nonalcoholic steatohepatitis. Eur. J. Nutr. 2017, 57, 861-876. [CrossRef]

39. Boursier, J.; Mueller, O.; Barret, M.; Machado, M.V.; Fizanne, L.; Araujo-Perez, F.; Guy, C.D.; Seed, P.C.; Rawls, J.F.; David, L.A.; et al. The severity of nonalcoholic fatty liver disease is associated with gut dysbiosis and shift in the metabolic function of the gut microbiota. Hepatology 2015, 63, 764-775. [CrossRef]

40. Bastian, W.P.; Hasan, I.; Lesmana, C.R.A.; Rinaldi, I.; Gani, R.A. Gut Microbiota Profiles in Nonalcoholic Fatty Liver Disease and Its Possible Impact on Disease Progression Evaluated with Transient Elastography: Lesson Learnt from 60 Cases. Case Rep. Gastroenterol. 2019, 13, 125-133. [CrossRef]

41. Turner, J.R. Intestinal mucosal barrier function in health and disease. Nat. Rev. Immunol. 2009, 9, 799-809. [CrossRef] [PubMed]

42. Volynets, V.; Küper, M.A.; Strahl, S.; Maier, I.B.; Spruss, A.; Wagnerberger, S.; Königsrainer, A.; Bischoff, S.C.; Bergheim, I. Nutrition, intestinal permeability, and blood ethanol levels are altered in patients with non-alcoholic fatty liver disease (NAFLD). Dig. Dis. Sci. 2012, 57, 1932-1941. [CrossRef] [PubMed]

43. Bieghs, V.; Trautwein, C. The innate immune response during liver inflammation and metabolic disease. Trends Immunol. 2013, 34, 446-452. [CrossRef] [PubMed]

44. Reid, D.T.; Reyes, J.L.; McDonald, B.A.; Vo, T.; Reimer, R.A.; Eksteen, B. Kupffer Cells Undergo Fundamental Changes during the Development of Experimental NASH and Are Critical in Initiating Liver Damage and Inflammation. PLoS ONE 2016, 11, e0159524. [CrossRef]

45. Miura, K.; Ohnishi, H. Role of gut microbiota and Toll-like receptors in nonalcoholic fatty liver disease. World J. Gastroenterol. 2014, 20, 7381-7391. [CrossRef]

46. Spruss, A.; Kanuri, G.; Wagnerberger, S.; Haub, S.; Bischoff, S.C.; Bergheim, I. Toll-like receptor 4 is involved in the development of fructose-induced hepatic steatosis in mice. Hepatology 2009, 50, 1094-1104. [CrossRef] [PubMed]

47. Ye, D.; Li, F.Y.L.; Lam, K.S.L.; Li, H.; Jia, W.; Wang, Y.; Man, K.; Lo, C.M.; Li, X.; Xu, A. Toll-like receptor-4 mediates obesity-induced non-alcoholic steatohepatitis through activation of X-box binding protein-1 in mice. Gut 2012, 61, 1058-1067. [CrossRef]

48. Csak, T.; Velayudham, A.; Hritz, I.; Petrasek, J.; Levin, I.; Lippai, D.; Catalano, D.; Mandrekar, P.; Dolganiuc, A.; Kurt-Jones, E.; et al. Deficiency in myeloid differentiation factor-2 and toll-like receptor 4 expression attenuates nonal-coholic steatohepatitis and fibrosis in mice. Am. J. Physiol. Gastrointest. Liver Physiol. 2011, 300, G433-G441. [CrossRef] [PubMed]

49. Tsukumo, D.M.; Filho, M.A.C.; Carvalheira, J.B.; Prada, P.O.; Hirabara, S.M.; Schenka, A.A.; Araújo, E.P.; Vassallo, J.; Curi, R.; Velloso, L.A.; et al. Loss-of-Function Mutation in Toll-Like Receptor 4 Prevents Diet-Induced Obesity and Insulin Resistance. Diabetes 2007, 56, 1986-1998. [CrossRef]

50. Poggi, M.; Bastelica, D.; Gual, P.; Iglesias, M.A.; Gremeaux, T.; Knauf, C.; Peiretti, F.; Verdier, M.; Juhan-Vague, I.; Tanti, J.F.; et al. $\mathrm{C} 3 \mathrm{H} / \mathrm{HeJ}$ mice carrying a toll-like receptor 4 mutation are protected against the development of insulin resistance in white adipose tissue in response to a high-fat diet. Diabetologia 2007, 50, 1267-1276. [CrossRef]

51. Miura, K.; Kodama, Y.; Inokuchi, S.; Schnabl, B.; Aoyama, T.; Ohnishi, H.; Olefsky, J.M.; Brenner, D.A.; Seki, E. Toll-like receptor 9 promotes steatohepatitis by induction of interleukin-1beta in mice. Gastroenterology 2010, 139, 323-334.e7. [CrossRef]

52. Gadd, V.L.; Skoien, R.; Powell, E.; Fagan, K.J.; Winterford, C.; Horsfall, L.; Irvine, K.; Clouston, A.D. The portal inflammatory infiltrate and ductular reaction in human nonalcoholic fatty liver disease. Hepatology 2014, 59, 1393-1405. [CrossRef]

53. Miele, L.; Giorgio, V.; Liguori, A.; Petta, S.; Pastorino, R.; Arzani, D.; Alberelli, M.A.; Cefalo, C.; Marrone, G.; Biolato, M.; et al. Genetic susceptibility of increased intestinal permeability is associated with progressive liver disease and diabetes in patients with non-alcoholic fatty liver disease. Nutr. Metab. Cardiovasc. Dis. 2020, 30, 2103-2110. [CrossRef] [PubMed]

54. Rahman, K.; Desai, C.; Iyer, S.S.; Thorn, N.E.; Kumar, P.; Liu, Y.; Smith, T.; Neish, A.S.; Li, H.; Tan, S.; et al. Loss of Junctional Adhesion Molecule a Promotes Severe Steatohepatitis in Mice on a Diet High in Saturated Fat, Fructose, and Cholesterol. Gastroenterology 2016, 151, 733-746.e12. [CrossRef] [PubMed]

55. Gäbele, E.; Dostert, K.; Hofmann, C.; Wiest, R.; Schölmerich, J.; Hellerbrand, C.; Obermeier, F. DSS induced colitis increases portal LPS levels and enhances hepatic inflammation and fibro-genesis in experimental NASH. J. Hepatol. 2011, 55, 1391-1399. [CrossRef]

56. Miele, L.; Valenza, V.; La Torre, G.; Montalto, M.; Cammarota, G.; Ricci, R.; Mascianà, R.; Forgione, A.; Gabrieli, M.L.; Perotti, G.; et al. Increased intestinal permeability and tight junction alterations in nonalcoholic fatty liver disease. Hepatology 2009, 49, 1877-1887. [CrossRef] 
57. Luther, J.; Garber, J.J.; Khalili, H.; Dave, M.; Bale, S.S.; Jindal, R.; Motola, D.L.; Luther, S.; Bohr, S.; Jeoung, S.W.; et al. Hepatic Injury in Nonalcoholic Steatohepatitis Contributes to Altered Intestinal Permeability. Cell. Mol. Gastroenterol. Hepatol. 2015, 1, 222-232. [CrossRef] [PubMed]

58. Giorgio, V.; Miele, L.; Principessa, L.; Ferretti, F.; Villa, M.P.; Negro, V.; Grieco, A.; Alisi, A.; Nobili, V. Intestinal permeability is increased in children with non-alcoholic fatty liver disease, and correlates with liver disease severity. Dig. Liver Dis. 2014, 46, 556-560. [CrossRef]

59. Krajmalnik-Brown, R.; Ilhan, Z.-E.; Kang, D.-W.; DiBaise, J.K. Effects of gut microbes on nutrient absorption and energy regulation. Nutr. Clin. Pract. 2012, 27, 201-214. [CrossRef] [PubMed]

60. Arora, T.; Sharma, R. Fermentation potential of the gut microbiome: Implications for energy homeostasis and weight management. Nutr. Rev. 2011, 69, 99-106. [CrossRef]

61. Wong, J.M.W.; de Souza, R.; Kendall, C.W.C.; Emam, A.; Jenkins, D.J.A. Colonic Health: Fermentation and Short Chain Fatty Acids. J. Clin. Gastroenterol. 2006, 40, 235-243. [CrossRef] [PubMed]

62. Turnbaugh, P.J.; Hamady, M.; Yatsunenko, T.; Cantarel, B.L.; Duncan, A.; Ley, R.E.; Sogin, M.L.; Jones, W.J.; Roe, B.A.; Affourtit, J.P.; et al. A core gut microbiome in obese and lean twins. Nat. Cell Biol. 2008, 457, 480-484. [CrossRef]

63. Ley, R.E.; Turnbaugh, P.J.; Klein, S.; Gordon, J.I. Microbial ecology: Human gut microbes associated with obesity. Nature 2006, 444, 1022-1023. [CrossRef]

64. Murphy, E.F.; Cotter, P.D.; Healy, S.; Marques, T.M.; O’Sullivan, O.; Fouhy, F.; Clarke, S.F.; O’Toole, P.W.; Quigley, E.M.; Stanton, C.; et al. Composition and energy harvesting capacity of the gut microbiota: Relationship to diet, obesity and time in mouse models. Gut 2010, 59, 1635-1642. [CrossRef] [PubMed]

65. Turnbaugh, P.J.; Ley, R.E.; Mahowald, M.A.; Magrini, V.; Mardis, E.R.; Gordon, J.I. An obesity-associated gut microbiome with increased capacity for energy harvest. Nat. Cell Biol. 2006, 444, 1027-1031. [CrossRef] [PubMed]

66. Blumberg, H.; Mccollum, E.V.; Albanese, A.A.; Buschke, W. The prevention by choline of liver cirrhosis in rats on high fat, low protein diets. Science 1941, 93, 598-599. [CrossRef]

67. Spencer, M.; Hamp, T.J.; Reid, R.; Fischer, L.M.; Zeisel, S.H.; Fodor, A.A. Association Between Composition of the Human Gastrointestinal Microbiome and Development of Fatty Liver with Choline Deficiency. Gastroenterology 2011, 140, 976-986. [CrossRef]

68. Dumas, M.E.; Barton, R.H.; Toye, A.; Cloarec, O.; Blancher, C.; Rothwell, A.; Fearnside, J.; Tatoud, R.; Blanc, V.; Lindon, J.C.; et al. Metabolic profiling reveals a contribution of gut microbiota to fatty liver phenotype in insulin resistant mice. Proc. Natl. Acad. Sci. USA 2006, 103, 12511-12516. [CrossRef]

69. Jiang, X.C.; Li, Z.; Liu, R.; Yang, X.P.; Pan, M.; Lagrost, L.; Fisher, E.A.; Williams, K.J. Phospholipid transfer protein deficiency impairs apolipoprotein-B secretion from hepatocytes by stimulating a proteolytic pathway through a relative deficiency of vitamin E and an increase in intracellular oxidants. J. Biol. Chem. 2005, 280, 18336-18340. [CrossRef]

70. Wang, Z.; Klipfell, E.; Bennett, B.J.; Koeth, R.; Levison, B.S.; Dugar, B.; Feldstein, A.E.; Britt, E.B.; Fu, X.; Chung, Y.M.; et al. Gut flora metabolism of phosphatidylcholine promotes cardiovascular disease. Nature 2011, 472, 57-63. [CrossRef]

71. Tang, W.W.; Wang, Z.; Levison, B.S.; Koeth, R.A.; Britt, E.B.; Fu, X.; Wu, Y.; Hazen, S.L. Intestinal Microbial Metabolism of Phosphatidylcholine and Cardiovascular Risk. N. Engl. J. Med. 2013, 368, 1575-1584. [CrossRef]

72. Tan, J.; McKenzie, C.; Potamitis, M.; Thorburn, A.N.; Mackay, C.R.; Macia, L. The Role of Short-Chain Fatty Acids in Health and Disease. Adv. Immunol. 2014, 121, 91-119. [CrossRef]

73. McNeil, N.I.; Cummings, J.H.; James, W.P.T. Short chain fatty-acid absorption by human large intestine. Gut 1978, 19, 819-822. [CrossRef] [PubMed]

74. Schwiertz, A.; Taras, D.; Schaefer, K.; Beijer, S.; Bos, N.A.; Donus, C.; Hardt, P.D. Microbiota and SCFA in Lean and Overweight Healthy Subjects. Obesity 2010, 18, 190-195. [CrossRef]

75. Rahat-Rozenbloom, S.; Fernandes, J.; Gloor, G.; Wolever, T.M.S. Evidence for greater production of colonic short-chain fatty acids in overweight than lean humans. Int. J. Obes. 2014, 38, 1525-1531. [CrossRef] [PubMed]

76. Canfora, E.E.; Meex, R.C.R.; Venema, K.; Blaak, E.E. Gut microbial metabolites in obesity, NAFLD and T2DM. Nat. Rev. Endocrinol. 2019, 15, 261-273. [CrossRef] [PubMed]

77. Byrne, C.S.; Chambers, E.S.; Morrison, D.J.; Frost, G. The role of short chain fatty acids in appetite regulation and energy homeostasis. Int. J. Obes. 2015, 39, 1331-1338. [CrossRef] [PubMed]

78. Kimura, I.; Ozawa, K.; Inoue, D.; Imamura, T.; Kimura, K.; Maeda, T.; Terasawa, K.; Kashihara, D.; Hirano, K.; Tani, T.; et al. The gut microbiota suppresses insulin-mediated fat accumulation via the short-chain fatty acid receptor GPR43. Nat. Commun. 2013, 4, 1829. [CrossRef]

79. Maslowski, K.M.; Vieira, A.T.; Ng, A.; Kranich, J.; Sierro, F.; Yu, D.; Schilter, H.C.; Rolph, M.S.; Mackay, F.; Artis, D.; et al. Regulation of inflammatory responses by gut microbiota and chemoattractant receptor GPR43. Nature 2009, 461, 1282-1286. [CrossRef]

80. Macia, L.; Tan, J.; Vieira, A.T.; Leach, K.; Stanley, D.; Luong, S.; Maruya, M.; McKenzie, C.I.; Hijikata, A.; Wong, C.; et al. Metabolite-sensing receptors GPR43 and GPR109A facilitate dietary fibre-induced gut homeostasis through regulation of the inflammasome. Nat. Commun. 2015, 6, 6734. [CrossRef] 
81. Rau, M.; Rehman, A.; Dittrich, M.; Groen, A.K.; Hermanns, H.M.; Seyfried, F.; Beyersdorf, N.; Dandekar, T.; Rosenstiel, P.; Geier, A. Fecal SCFAs and SCFA-producing bacteria in gut microbiome of human NAFLD as a putative link to systemic T-cell activation and advanced disease. United Eur. Gastroenterol. J. 2018, 6, 1496-1507. [CrossRef] [PubMed]

82. Lefebvre, P.; Cariou, B.; Lien, F.; Kuipers, F.; Staels, B. Role of Bile Acids and Bile Acid Receptors in Metabolic Regulation. Physiol. Rev. 2009, 89, 147-191. [CrossRef]

83. Asgharpour, A.; Kumar, D.P.; Sanyal, A.J. Bile acids: Emerging role in management of liver diseases. Hepatol. Int. 2015, 9, 527-533. [CrossRef] [PubMed]

84. Claudel, T.; Staels, B.; Kuipers, F. The Farnesoid X receptor: A molecular link between bile acid and lipid and glucose metabolism. Arterioscler. Thromb. Vasc. Biol. 2005, 25, 2020-2030. [CrossRef] [PubMed]

85. Chávez-Talavera, O.; Tailleux, A.; Lefebvre, P.; Staels, B. Bile Acid Control of Metabolism and Inflammation in Obesity, Type 2 Diabetes, Dyslipidemia, and Nonalcoholic Fatty Liver Disease. Gastroenterology 2017, 152, 1679-1694. [CrossRef] [PubMed]

86. Swann, J.R.; Want, E.J.; Geier, F.M.; Spagou, K.; Wilson, I.D.; Sidaway, J.E.; Nicholson, J.K.; Holmes, E. Systemic gut microbial modulation of bile acid metabolism in host tissue compartments. Proc. Natl. Acad. Sci. USA 2010, 108, 4523-4530. [CrossRef]

87. Wahlström, A.; Sayin, S.I.; Marschall, H.-U.; Bäckhed, F. Intestinal Crosstalk between Bile Acids and Microbiota and Its Impact on Host Metabolism. Cell Metab. 2016, 24, 41-50. [CrossRef]

88. Wahlström, A.; Kovatcheva-Datchary, P.; Ståhlman, M.; Bäckhed, F.; Marschall, H.-U. Crosstalk between Bile Acids and Gut Microbiota and Its Impact on Farnesoid X Receptor Signalling. Dig. Dis. 2017, 35, 246-250. [CrossRef]

89. Ridlon, J.M.; Alves, J.M.; Hylemon, P.B.; Bajaj, J.S. Cirrhosis, bile acids and gut microbiota: Unraveling a complex relationship. Gut Microbes 2013, 4, 382-387. [CrossRef] [PubMed]

90. Sayin, S.I.; Wahlström, A.; Felin, J.; Jäntti, S.; Marschall, H.-U.; Bamberg, K.; Angelin, B.; Hyötyläinen, T.; Orešič, M.; Bäckhed, F. Gut microbiota regulates bile acid metabolism by reducing the levels of tauro-beta-muricholic acid, a naturally occurring FXR antagonist. Cell Metab. 2013, 17, 225-235. [CrossRef]

91. Selwyn, F.; Csanaky, I.L.; Zhang, Y.; Klaassen, C.D. Importance of Large Intestine in Regulating Bile Acids and Glucagon-Like Peptide-1 in Germ-Free Mice. Drug Metab. Dispos. 2015, 43, 1544-1556. [CrossRef]

92. Gérard, P. Metabolism of Cholesterol and Bile Acids by the Gut Microbiota. Pathogens 2013, 3, 14-24. [CrossRef] [PubMed]

93. Mouzaki, M.; Wang, A.Y.; Bandsma, R.; Comelli, E.M.; Arendt, B.M.; Zhang, L.; Fung, S.; Fischer, S.E.; McGilvray, I.G.; Allard, J.P. Bile Acids and Dysbiosis in Non-Alcoholic Fatty Liver Disease. PLoS ONE 2016, 11, e0151829. [CrossRef]

94. Jiao, N.; Baker, S.S.; Chapa-Rodriguez, A.; Liu, W.; Nugent, C.A.; Tsompana, M.; Mastrandrea, L.; Buck, M.J.; Baker, R.D.; Genco, R.J.; et al. Suppressed hepatic bile acid signalling despite elevated production of primary and secondary bile acids in NAFLD. Gut 2018, 67, 1881-1891. [CrossRef] [PubMed]

95. Yang, Z.X.; Shen, W.; Sun, H. Effects of nuclear receptor FXR on the regulation of liver lipid metabolism in patients with non-alcoholic fatty liver disease. Hepatol. Int. 2010, 4, 741-748. [CrossRef]

96. Zhu, Y.; Liu, H.; Zhang, M.; Guo, G.L. Fatty liver diseases, bile acids, and FXR. Acta Pharm. Sin. B 2016, 6, 409-412. [CrossRef] [PubMed]

97. Armstrong, L.E.; Guo, G.L. Role of FXR in liver inflammation during nonalcoholic steatohepatitis. Curr. Pharmacol. Rep. 2017, 3, 92-100. [CrossRef] [PubMed]

98. David, L.A.; Maurice, C.F.; Carmody, R.N.; Gootenberg, D.; Button, J.E.; Wolfe, B.E.; Ling, A.V.; Devlin, A.S.; Varma, Y.; Fischbach, M.; et al. Diet rapidly and reproducibly alters the human gut microbiome. Nat. Cell Biol. 2013, 505, 559-563. [CrossRef]

99. Wu, G.D.; Chen, J.; Hoffmann, C.; Bittinger, K.; Chen, Y.Y.; Keilbaugh, S.A.; Bewtra, M.; Knights, D.; Walters, W.A.; Knight, R.; et al. Linking long-term dietary patterns with gut microbial enterotypes. Science 2011, 334, 105-108. [CrossRef]

100. Zeng, H.; Liu, J.; Jackson, M.I.; Zhao, F.-Q.; Yan, L.; Combs, G.F. Fatty Liver Accompanies an Increase in Lactobacillus Species in the Hind Gut of C57BL/6 Mice Fed a High-Fat Diet. J. Nutr. 2013, 143, 627-631. [CrossRef]

101. Geypens, B.; Claus, D.; Evenepoel, P.; Hiele, M.; Maes, B.; Peeters, M.; Rutgeerts, P.; Ghoos, Y. Influence of dietary protein supplements on the formation of bacterial metabolites in the colon. Gut 1997, 41, 70-76. [CrossRef]

102. Russell, W.; Gratz, S.W.; Duncan, S.H.; Holtrop, G.; Ince, J.; Scobbie, L.; Duncan, G.; Johnstone, A.M.; Lobley, G.; Wallace, R.J.; et al. High-protein, reduced-carbohydrate weight-loss diets promote metabolite profiles likely to be detrimental to colonic health. Am. J. Clin. Nutr. 2011, 93, 1062-1072. [CrossRef]

103. Andriamihaja, M.; Davila, A.-M.; Eklou-Lawson, M.; Petit, N.; Delpal, S.; Allek, F.; Blais, A.; Delteil, C.; Tomé, D.; Blachier, F. Colon luminal content and epithelial cell morphology are markedly modified in rats fed with a high-protein diet. Am. J. Physiol. Gastrointest. Liver Physiol. 2010, 299, G1030-G1037. [CrossRef] [PubMed]

104. Yao, C.K.; Muir, J.G.; Gibson, P.R. Review article: Insights into colonic protein fermentation, its modulation and potential health implications. Aliment. Pharmacol. Ther. 2015, 43, 181-196. [CrossRef] [PubMed]

105. Bansal, T.; Alaniz, R.C.; Wood, T.; Jayaraman, A. The bacterial signal indole increases epithelial-cell tight-junction resistance and attenuates indicators of inflammation. Proc. Natl. Acad. Sci. USA 2009, 107, 228-233. [CrossRef]

106. Beaumont, M.; Neyrinck, A.; Olivares, M.; Rodriguez, J.; Serra, A.D.R.; Roumain, M.; Bindels, L.B.; Cani, P.D.; Evenepoel, P.; Muccioli, G.G.; et al. The gut microbiota metabolite indole alleviates liver inflammation in mice. FASEB J. 2018, 32, 6681-6693. [CrossRef] [PubMed]

107. Ascha, M.S.; Hanouneh, I.A.; Lopez, R.; Tamimi, T.A.; Feldstein, A.F.; Zein, N.N. The incidence and risk factors of hepatocellular carcinoma in patients with nonalcoholic steatohepatitis. Hepatology 2010, 51, 1972-1978. [CrossRef] 
108. Kanwal, F.; Kramer, J.R.; Mapakshi, S.; Natarajan, Y.; Chayanupatkul, M.; Richardson, P.A.; Li, L.; Desiderio, R.; Thrift, A.P.; Asch, S.M.; et al. Risk of Hepatocellular Cancer in Patients with Non-Alcoholic Fatty Liver Disease. Gastroenterology 2018, 155, 1828-1837. [CrossRef]

109. Wong, R.J.; Cheung, R.; Ahmed, A. Nonalcoholic steatohepatitis is the most rapidly growing indication for liver transplantation in patients with hepatocellular carcinoma in the U.S. Hepatology 2013, 59, 2188-2195. [CrossRef] [PubMed]

110. Ertle, J.; Dechêne, A.; Sowa, J.P.; Penndorf, V.; Herzer, K.; Kaiser, G.; Schlaak, J.F.; Gerken, G.; Syn, W.K.; Canbay, A. Non-alcoholic fatty liver disease progresses to hepatocellular carcinoma in the absence of apparent cirrhosis. Int. J. Cancer 2011, 128, 2436-2443. [CrossRef]

111. Piscaglia, F.; Svegliati-Baroni, G.; Barchetti, A.; Pecorelli, A.; Marinelli, S.; Tiribelli, C.; Bellentani, S.; HCC-NAFLD Italian Study Group. Clinical patterns of hepatocellular carcinoma in nonalcoholic fatty liver disease: A multicenter prospective study. Hepatology 2016, 63, 827-838. [CrossRef]

112. Anstee, Q.M.; Reeves, H.L.; Kotsiliti, E.; Govaere, O.; Heikenwalder, M. From NASH to HCC: Current concepts and future challenges. Nat. Rev. Gastroenterol. Hepatol. 2019, 16, 411-428. [CrossRef]

113. Tanaka, S.; Miyanishi, K.; Kobune, M.; Kawano, Y.; Hoki, T.; Kubo, T.; Hayashi, T.; Sato, T.; Sato, Y.; Takimoto, R.; et al. Increased hepatic oxidative DNA damage in patients with nonalcoholic steatohepatitis who develop hepatocellular carcinoma. $J$. Gastroenterol. 2013, 48, 1249-1258. [CrossRef] [PubMed]

114. Gomes, A.L.; Teijeiro, A.; Burén, S.; Tummala, K.S.; Yilmaz, M.; Waisman, A.; Theurillat, J.P.; Perna, C.; Djouder, N. Metabolic inflammation-associated IL-17A causes non-alcoholic steatohepatitis and hepato-cellular carcinoma. Cancer Cell 2016, 30, 161-175. [CrossRef] [PubMed]

115. Wolf, M.J.; Adili, A.; Piotrowitz, K.; Abdullah, Z.; Boege, Y.; Stemmer, K.; Ringelhan, M.; Simonavicius, N.; Egger, M.; Wohlleber, D.; et al. Metabolic activation of intrahepatic CD8+T cells and NKT cells causes nonalcoholic steatohepatitis and liver cancer via cross-talk with hepatocytes. Cancer Cell 2014, 26, 549-564. [CrossRef] [PubMed]

116. Schwabe, R.F.; Greten, T.F. Gut microbiome in HCC-Mechanisms, diagnosis and therapy. J. Hepatol. 2020, 72, 230-238. [CrossRef] [PubMed]

117. Yu, L.-X.; Yan, H.-X.; Liu, Q.; Yang, W.; Wu, H.-P.; Dong, W.; Tang, L.; Lin, Y.; He, Y.-Q.; Zou, S.-S.; et al. Endotoxin accumulation prevents carcinogen-induced apoptosis and promotes liver tumorigenesis in rodents. Hepatology 2010, 52, 1322-1333. [CrossRef]

118. Dapito, D.H.; Mencin, A.; Gwak, G.Y.; Pradere, J.P.; Jang, M.K.; Mederacke, I.; Caviglia, J.M.; Khiabanian, H.; Adeyemi, A.; Bataller, R.; et al. Promotion of hepatocellular carcinoma by the intestinal microbiota and TLR4. Cancer Cell 2012, 21, 504-516. [CrossRef]

119. Li, J.; Sung, C.Y.J.; Lee, N.; Ni, Y.; Pihlajamäki, J.; Panagiotou, G.; El-Nezami, H. Probiotics modulated gut microbiota suppresses hepatocellular carcinoma growth in mice. Proc. Natl. Acad. Sci. USA 2016, 113, E1306-E1315. [CrossRef]

120. Xie, G.; Wang, X.; Huang, F.; Zhao, A.; Chen, W.; Yan, J.; Zhang, Y.; Lei, S.; Ge, K.; Zheng, X.; et al. Dysregulated hepatic bile acids collaboratively promote liver carcinogenesis. Int. J. Cancer 2016, 139, 1764-1775. [CrossRef]

121. Yamada, S.; Takashina, Y.; Watanabe, M.; Nagamine, R.; Saito, Y.; Kamada, N.; Saito, H. Bile acid metabolism regulated by the gut microbiota promotes non-alcoholic steatohepatitis-associated hepatocellular carcinoma in mice. Oncotarget 2018, 9, 9925-9939. [CrossRef]

122. Ponziani, F.R.; Bhoori, S.; Castelli, C.; Putignani, L.; Rivoltini, L.; del Chierico, F.; Sanguinetti, M.; Morelli, D.; Sterbini, F.P.; Petito, V.; et al. Hepatocellular Carcinoma is Associated with Gut Microbiota Profile and Inflammation in Nonalcoholic Fatty Liver Disease. Hepatology 2018, 69, 107-120. [CrossRef] [PubMed]

123. Loomba, R.; Seguritan, V.; Li, W.; Long, T.; Klitgord, N.; Bhatt, A.; Dulai, P.S.; Caussy, C.; Bettencourt, R.; Highlander, S.K.; et al. Gut Microbiome-Based Metagenomic Signature for Non-invasive Detection of Advanced Fibrosis in Human Nonalcoholic Fatty Liver Disease. Cell Metab. 2017, 25, 1054-1062.e5. [CrossRef] [PubMed]

124. Suk, K.T.; Kim, D.J. Gut microbiota: Novel therapeutic target for nonalcoholic fatty liver disease. Expert Rev. Gastroenterol. Hepatol. 2019, 13, 193-204. [CrossRef] [PubMed]

125. Bergheim, I.; Weber, S.; Vos, M.; Krämer, S.; Volynets, V.; Kaserouni, S.; McClain, C.J.; Bischoff, S.C. Antibiotics protect against fructose-induced hepatic lipid accumulation in mice: Role of endotoxin. J. Hepatol. 2008, 48, 983-992. [CrossRef]

126. Gangarapu, V.; Ince, A.T.; Baysal, B.; Kayar, Y.; Kılıç, U.; Gök, U.; Uysal, O.; Şenturk, H. Efficacy of rifaximin on circulating endotoxins and cytokines in patients with nonalcoholic fatty liver disease. Eur. J. Gastroenterol. Hepatol. 2015, 27, 840-845. [CrossRef]

127. Cobbold, J.F.; Atkinson, S.; Marchesi, J.; Smith, A.; Wai, S.N.; Stove, J.; Shojaee-Moradie, F.; Jackson, N.; Umpleby, A.M.; Fitzpatrick, J.; et al. Rifaximin in non-alcoholic steatohepatitis: An open-label pilot study. Hepatol. Res. 2017, 48, 69-77. [CrossRef]

128. Abdel-Razik, A.; Mousa, N.; Shabana, W.; Refaey, M.; Elzehery, R.; Elhelaly, R.; Zalata, K.; Abdelsalam, M.; Eldeeb, A.A.; Awad, M.; et al. Rifaximin in nonalcoholic fatty liver disease: Hit multiple targets with a single shot. Eur. J. Gastroenterol. Hepatol. 2018, 30, 1237-1246. [CrossRef] [PubMed]

129. Ponziani, F.R.; Scaldaferri, F.; Petito, V.; Paroni Sterbini, F.; Pecere, S.; Lopetuso, L.R.; Palladini, A.; Gerardi, V.; Masucci, L.; Pompili, M.; et al. The role of antibiotics in gut microbiota modulation: The eubiotic effects of rifaximin. Dig. Dis. 2016, 34, 269-278. [CrossRef] 
130. Gibson, G.R.; Hutkins, R.; Sanders, M.E.; Prescott, S.L.; Reimer, R.A.; Salminen, S.J.; Scott, K.; Stanton, C.; Swanson, K.S.; Cani, P.D.; et al. Expert consensus document: The International Scientific Association for Probiotics and Prebiotics (ISAPP) consensus statement on the definition and scope of prebiotics. Nat. Rev. Gastroenterol. Hepatol. 2017, 14, 491-502. [CrossRef]

131. Parnell, J.A.; Raman, M.; Rioux, K.P.; Reimer, R.A. The potential role of prebiotic fibre for treatment and management of non-alcoholic fatty liver disease and associated obesity and insulin resistance. Liver Int. 2011, 32, 701-711. [CrossRef]

132. Daubioul, C.; Horsmans, Y.; Lambert, P.; Danse, E.; Delzenne, N.M. Effects of oligofructose on glucose and lipid metabolism in patients with nonalcoholic steatohepatitis: Results of a pilot study. Eur. J. Clin. Nutr. 2005, 59, 723-726. [CrossRef]

133. Rocha, R.; Cotrim, H.P.; Siqueira, A.C.; Floriano, S. Non alcoholic fatty liver disease: Treatment with soluble fibres. Arq. Gastroenterol. 2007, 44, 350-352. [CrossRef]

134. Ebrahimi-Mameghani, M.; Aliashrafi, S.; Javadzadeh, Y.; AsghariJafarabadi, M. The Effect of Chlorella vulgaris Supplementation on Liver Enzymes, Serum Glucose and Lipid Profile in Patients with Non-Alcoholic Fatty Liver Disease. Health Promot. Perspect. 2014, 4, 107-115. [CrossRef] [PubMed]

135. Akbarzadeh, Z.; Nourian, M.; Askari, G.; Maracy, M.R.; Rafiei, R. The effect of psyllium on anthropometric measurements and liver enzymes in overweight or obese adults with nonalcoholic fatty liver disease (NAFLD). J. Isfahan Med. School 2015, 33, 1771-1783.

136. Lambert, J.E.; Parnell, J.A.; Eksteen, B.; Raman, M.; Bomhof, M.R.; Rioux, K.P.; Madsen, K.L.; Reimer, R.A. Gut microbiota manipulation with prebiotics in patients with non-alcoholic fatty liver disease: A randomized controlled trial protocol. $B M C$ Gastroenterol. 2015, 15, 1-13. [CrossRef] [PubMed]

137. Javadi, L.; Ghavami, M.; Khoshbaten, M.; Safaiyan, A.; Barzegari, A.; Gargari, B.P. The Effect of Probiotic and/or Prebiotic on Liver Function Tests in Patients with Nonalcoholic Fatty Liver Disease: A Double Blind Randomized Clinical Trial. Iran. Red Crescent Med. J. 2017, 19. [CrossRef]

138. Loman, B.R.; Hernández-Saavedra, D.; An, R.; Rector, R.S. Prebiotic and probiotic treatment of nonalcoholic fatty liver disease: A systematic review and meta-analysis. Nutr. Rev. 2018, 76, 822-839. [CrossRef]

139. Loguercio, C.; Federico, A.; Tuccillo, C.; Terracciano, F.; D’Auria, M.V.; De Simone, C.; Del Vecchio Blanco, C. Beneficial effects of a probiotic VSL\#3 on parameters of liver dysfunction in chronic liver diseases. J. Clin. Gastroenterol. 2005, 39, 540-543. [PubMed]

140. Aller, R.; De Luis, D.A.; Izaola, O.; Conde, R.; Sagrado, M.G.; Primo, D.; De La Fuente, B.; Gonzalez, J. Effect of a probiotic on liver aminotransferases in nonalcoholic fatty liver disease patients: A double blind randomized clinical trial. Eur. Rev. Med Pharmacol. Sci. 2011, 15, 1090-1095.

141. Vajro, P.; Mandato, C.; Licenziati, M.R.; Franzese, A.; Vitale, D.F.; Lenta, S.; Caropreso, M.; Vallone, G.; Meli, R. Effects of Lactobacillus rhamnosus strain GG in pediatric obesity-related liver disease. J. Pediatr. Gastroenterol. Nutr. 2011, 52, 740-743. [CrossRef] [PubMed]

142. Wong, V.W.-S.; Wong, G.L.-H.; Chim, A.M.-L.; Chu, W.; Yeung, D.K.-W.; Li, K.C.-T.; Chan, H.L.-Y. Treatment of nonalcoholic steatohepatitis with probiotics. A proof-of-concept study. Ann. Hepatol. 2013, 12, 256-262. [CrossRef]

143. Shavakhi, A.; Minakari, M.; Firouzian, H.; Assali, R.; Hekmatdoost, A.; Ferns, G. Effect of a Probiotic and Metformin on Liver Aminotransferases in Non-alcoholic Steatohepatitis: A Double Blind Randomized Clinical Trial. Int. J. Prev. Med. 2013, 4, 531-537. [PubMed]

144. Nabavi, S.; Rafraf, M.; Somi, M.H.; Homayouni-Rad, A.; Asghari-Jafarabadi, M. Effects of probiotic yogurt consumption on metabolic factors in individuals with nonalcoholic fatty liver disease. J. Dairy Sci. 2014, 97, 7386-7393. [CrossRef] [PubMed]

145. Alisi, A.; Bedogni, G.; Baviera, G.; Giorgio, V.; Porro, E.; Paris, C.; Giammaria, P.; Reali, L.; Anania, F.; Nobili, V. Randomised clinical trial: The beneficial effects of VSL\#3 in obese children with non-alcoholic steatohepatitis. Aliment. Pharmacol. Ther. 2014, 39, 1276-1285. [CrossRef] [PubMed]

146. Sepideh, A.; Karim, P.; Hossein, A.; Leila, R.; Hamdollah, M.; Mohammad, E.G.; Mojtaba, S.; Mohammad, S.; Ghader, G.; Seyed Moayed, A. Effects of multistrain probiotic supplementation on glycemic and inflammatory indices in patients with nonalcoholic fatty liver disease: A double-blind randomized clinical trial. J. Am. Coll. Nutr. 2016, 35, 500-505. [CrossRef]

147. Kobyliak, N.; Abenavoli, L.; Mykhalchyshyn, G.; Kononenko, L.; Boccuto, L.; Kyriienko, D.; Dynnyk, O. A Multi-strain Probiotic Reduces the Fatty Liver Index, Cytokines and Aminotransferase levels in NAFLD Patients: Evidence from a Randomized Clinical Trial. J. Gastrointest. Liver Dis. 2018, 27, 41-49. [CrossRef]

148. Duseja, A.; Acharya, S.K.; Mehta, M.; Chhabra, S.; Rana, S.; Das, A.; Dattagupta, S.; Dhiman, R.K.; Chawla, Y.K. Shalimar High potency multistrain probiotic improves liver histology in non-alcoholic fatty liver disease (NAFLD): A randomised, double-blind, proof of concept study. BMJ Open Gastroenterol. 2019, 6, e000315. [CrossRef]

149. Wan, M.L.Y.; El-Nezami, H. Targeting gut microbiota in hepatocellular carcinoma: Probiotics as a novel therapy. HepatoBiliary Surg. Nutr. 2018, 7, 11-20. [CrossRef]

150. Nicoletti, A.; Pompili, M.; Gasbarrini, A.; Ponziani, F.R. Going with the gut: Probiotics as a novel therapy for hepatocellular carcinoma. Hepatobiliary Surg. Nutr. 2019, 8, 295-297. [CrossRef]

151. Malaguarnera, M.; Vacante, M.; Antic, T.; Giordano, M.; Chisari, G.; Acquaviva, R.; Mastrojeni, S.; Malaguarnera, G.; Mistretta, A.; Volti, G.L.; et al. Bifidobacterium longum with Fructo-Oligosaccharides in Patients with Non Alcoholic Steatohepatitis. Dig. Dis. Sci. 2011, 57, 545-553. [CrossRef] 
152. Eslamparast, T.; Poustchi, H.; Zamani, F.; Sharafkhah, M.; Malekzadeh, R.; Hekmatdoost, A. Synbiotic supplementation in nonalcoholic fatty liver disease: A randomized, double-blind, placebo-controlled pilot study. Am. J. Clin. Nutr. 2014, 99, 535-542. [CrossRef] [PubMed]

153. Ferolla, S.M.; Couto, C.A.; Costa-Silva, L.; Armiliato, G.N.; Pereira, C.A.; Martins, F.S.; Ferrari, M.D.E.L.; Vilela, E.G.; Torres, H.O.; Cunha, A.S.; et al. Beneficial effect of synbiotic supplementation on hepatic steatosis and anthropometric parameters, but not on gut permeability in a population with nonalcoholic steatohepatitis. Nutrients 2016, 8, 397. [CrossRef]

154. Asgharian, A.; Askari, G.; Esmailzade, A.; Feizi, A.; Mohammadi, V. The effect of symbiotic supplementation on liver enzymes, C-reactive protein and ultrasound findings in patients with non-alcoholic fatty liver disease: A clinical trial. Int. J. Prev. Med. 2016, 7, 59.

155. Asgharian, A.; Mohammadi, V.; Gholi, Z.; Esmaillzade, A.; Feizi, A.; Askari, G. The Effect of Synbiotic Supplementation on Body Composition and Lipid Profile in Patients with NAFLD: A Randomized, Double Blind, Placebo-Controlled Clinical Trial Study. Iran. Red Crescent Med. J. 2017, 19. [CrossRef]

156. Mofidi, F.; Poustchi, H.; Yari, Z.; Nourinayyer, B.; Merat, S.; Sharafkhah, M.; Malekzadeh, R.; Hekmatdoost, A. Synbiotic supplementation in lean patients with non-alcoholic fatty liver disease: A pilot, randomised, double-blind, placebo-controlled, clinical trial. Br. J. Nutr. 2017, 117, 662-668. [CrossRef]

157. Hadi, A.; Mohammadi, H.; Miraghajani, M.; Ghaedi, E. Efficacy of synbiotic supplementation in patients with nonalcoholic fatty liver disease: A systematic review and meta-analysis of clinical trials: Synbiotic supplementation and NAFLD. Crit. Rev. Food Sci. Nutr. 2019, 59, 2494-2505. [CrossRef] [PubMed]

158. Scorletti, E.; Afolabi, P.R.; Miles, E.A.; Smith, D.E.; Almehmadi, A.; Alshathry, A.; Childs, C.E.; Del Fabbro, S.; Bilson, J.; Moy-ses, H.E.; et al. Synbiotics Alter Fecal Microbiomes, But Not Liver Fat or Fibrosis, in a Randomized Trial of Patients with Nonalcoholic Fatty Liver Disease. Gastroenterology 2020, 158, 1597-1610.e7. [CrossRef]

159. Ma, W.; Chen, J.; Meng, Y.; Yang, J.; Cui, Q.; Zhou, Y. Metformin Alters Gut Microbiota of Healthy Mice: Implication for Its Potential Role in Gut Microbiota Homeostasis. Front. Microbiol. 2018, 9, 1336. [CrossRef]

160. Forslund, K.; Hildebrand, F.; Nielsen, T.; Falony, G.; Le Chatelier, E.; Sunagawa, S.; Prifti, E.; Vieira-Silva, S.; Gudmundsdottir, V.; Pedersen, H.K.; et al. Disentangling type 2 diabetes and metformin treatment signatures in the human gut microbiota. Nature 2015, 528, 262-266. [CrossRef] [PubMed]

161. Wu, H.; Esteve, E.; Tremaroli, V.; Khan, M.T.; Caesar, R.; Mannerås-Holm, L.; Ståhlman, M.; Olsson, L.M.; Serino, M.; Planas-Fèlix, M.; et al. Metformin alters the gut microbiome of individuals with treatment-naive type 2 diabetes, contributing to the therapeutic effects of the drug. Nat. Med. 2017, 23, 850-858. [CrossRef]

162. de la Cuesta-Zuluaga, J.; Mueller, N.T.; Corrales-Agudelo, V.; Velásquez-Mejía, E.P.; Carmona, J.A.; Abad, J.M.; Escobar, J.S. Metformin is associated with higher relative abundance of mucin-degrading Akkermansia muciniphila and several short chain fatty acid-producing microbiota in the gut. Diabetes Care 2017, 40, 54-62. [CrossRef]

163. de Oliveira, S.; Houseright, R.A.; Graves, A.L.; Golenberg, N.; Korte, B.G.; Miskolci, V.; Huttenlocher, A. Metformin modulates innate immune-mediated inflammation and early progression of NAFLD-associated hepatocellular carcinoma in zebrafish. J. Hepatol. 2019, 70, 710-721. [CrossRef] [PubMed]

164. Haukeland, J.W.; Konopski, Z.; Eggesbo, H.B.; von Volkmann, H.L.; Raschpichler, G.; Bjoro, K.; Haaland, T.; Løberg, E.M.; Birkeland, K. Metformin in patients with non-alcoholic fatty liver disease: A randomized, controlled trial. Scand. J. Gastroenterol. 2009, 44, 853-860. [CrossRef] [PubMed]

165. Omer, Z.; Cetinkalp, S.; Akyildiz, M.; Yilmaz, F.; Batur, Y.; Yilmaz, C.; Akarca, U. Efficacy of insulin-sensitizing agents in nonalcoholic fatty liver disease. Eur. J. Gastroenterol. Hepatol. 2010, 22, 18-23. [CrossRef] [PubMed]

166. Razavizade, M.; Jamali, R.; Arj, A.; Matini, S.M.; Moraveji, A.; Taherkhani, E. The Effect of Pioglitazone and Metformin on Liver Function Tests, Insulin Resistance, and Liver Fat Content in Nonalcoholic Fatty Liver Disease: A Randomized Double Blinded Clinical Trial. Zahedan J. Res. Med Sci. 2013, 13, e9270. [CrossRef] [PubMed]

167. Rana, H.; Yadav, S.S.; Reddy, H.D.; Singhal, S.; Singh, D.K.; Usman, K. Comparative Effect of Insulin Sensitizers and Statin on Metabolic Profile and Ultrasonographical Score in Non Alcoholic Fatty Liver Disease. J. Clin. Diagn. Res. 2016, 10, OC19-OC23. [CrossRef] [PubMed]

168. Anushiravani, A.; Haddadi, N.; Pourfarmanbar, M.; Mohammadkarimi, V. Treatment options for nonalcoholic fatty liver disease: A double-blinded randomized placebo-controlled trial. Eur. J. Gastroenterol. Hepatol. 2019, 31, 613-617. [CrossRef]

169. Ubeda, M.; Lario, M.; Munoz, L.; Borrero, M.J.; Rodríguez-Serrano, M.; Sánchez-Díaz, A.M.; Del Campo, R.; Lledó, L.; Pastor, Ó.; García-Bermejo, L. Obeticholic acid reduces bacterial translocation and inhibits intestinal inflammation in cirrhotic rats. J. Hepatol. 2016, 64, 1049-1057. [CrossRef]

170. Neuschwander-Tetri, B.A.; Loomba, R.; Sanyal, A.J.; Lavine, J.E.; van Natta, M.L.; Abdelmalek, M.F.; Chalasani, N.; Dasarathy, S.; Diehl, A.M.; Hameed, B.; et al. Farnesoid X nuclear receptor ligand obeticholic acid for non-cirrhotic, non-alcoholic steatohepatitis (FLINT): A multicentre, randomised, placebo-controlled trial. Lancet 2015, 385, 956-965. [CrossRef]

171. Ratziu, V.; Sanyal, A.J.; Loomba, R.; Rinella, M.; Harrison, S.; Anstee, Q.M.; Goodman, Z.; Bedossa, P.; MacConell, L.; Shringarpure, R.; et al. REGENERATE: Design of a pivotal, randomised, phase 3 study evaluating the safety and efficacy of obeticholic acid in patients with fibrosis due to nonalcoholic steatohepatitis. Contemp. Clin. Trials 2019, 84, 105803. [CrossRef] [PubMed] 
172. Younossi, Z.M.; Ratziu, V.; Loomba, R.; Rinella, M.; Anstee, Q.M.; Goodman, Z.; Bedossa, P.; Geier, A.; Beckebaum, S.; Newsome, P.N.; et al. Obeticholic acid for the treatment of non-alcoholic steatohepatitis: Interim analysis from a multicentre, randomised, placebo-controlled phase 3 trial. Lancet 2019, 394, 2184-2196. [CrossRef]

173. Macnaughtan, J.; Ranchal, I.; Soeda, J.; Sawhney, R.; Oben, J.; Davies, N.; Mookerjee, R.; Marchesi, J.; Cox, J.; Jalan, R. Oral carbon therapy is associated with a selective modulation of the microbiome in cirrhotic rats which is associated with a significant reduction in inflammatory activation. Gut 2015, 64, A449-A450. [CrossRef]

174. Macnaughtan, J.; Soeda, J.; Mouralidarane, A.; Sandeman, S.; Howell, C.; Milkhalovsky, S.; Kozynchenko, O.; Tennison, S.; Davies, N.; Mookerjee, R.; et al. PMO-128 Effects of oral nanoporous carbon therapy in leptin null mice as a model of non-alcoholic steatohepatitis. Gut 2012, 61, A125. [CrossRef]

175. Diehl, A.M. JKB-121 in patients with nonalcoholic steatohepatitis: A phase 2 double-blind randomized control study. The International Liver Congress 2018 Abstract Book. J. Hepatol. 2018, 68 (Suppl. 1), S1-S926.

176. Harrison, S.A.; Rinella, M.E.; Abdelmalek, M.F.; Trotter, J.F.; Paredes, A.H.; Arnold, H.L.; Kugelmas, M.; Bashir, M.R.; Jaros, M.J.; Ling, L.; et al. NGM282 for treatment of non-alcoholic steatohepatitis: A multicentre, randomised, double-blind, placebocontrolled, phase 2 trial. Lancet 2018, 391, 1174-1185. [CrossRef]

177. Harrison, S.A.; Rossi, S.J.; Paredes, A.H.; Trotter, J.F.; Bashir, M.R.; Guy, C.D.; Banerjee, R.; Jaros, M.J.; Owers, S.; Baxter, B.A.; et al. NGM282 Improves Liver Fibrosis and Histology in 12 weeks in Patients With Nonalcoholic Steatohepatitis. Hepatology 2019, 25, 1198-1212. [CrossRef]

178. Lassailly, G.; Caiazzo, R.; Buob, D.; Pigeyre, M.; Verkindt, H.; Labreuche, J.; Raverdy, V.; Leteurtre, E.; Dharancy, S.; Louvet, A.; et al. Bariatric Surgery Reduces Features of Nonalcoholic Steatohepatitis in Morbidly Obese Patients. Gastroenterology 2015, 149, 379-388. [CrossRef]

179. Lassailly, G.; Caiazzo, R.; Ntandja-Wandji, L.-C.; Gnemmi, V.; Baud, G.; Verkindt, H.; Ningarhari, M.; Louvet, A.; Leteurtre, E.; Raverdy, V.; et al. Bariatric Surgery Provides Long-term Resolution of Nonalcoholic Steatohepatitis and Regression of Fibrosis. Gastroenterology 2020, 159, 1290-1301.e5. [CrossRef]

180. Zhang, H.; DiBaise, J.K.; Zuccolo, A.; Kudrna, D.; Braidotti, M.; Yu, Y.; Parameswaran, P.; Crowell, M.D.; Wing, R.; Rittmann, B.E.; et al. Human gut microbiota in obesity and after gastric bypass. Proc. Natl. Acad. Sci. USA 2009, 106, 2365-2370. [CrossRef]

181. Cătoi, A.F.; Pârvu, A.E.; Mureşan, A.; Busetto, L. Metabolic Mechanisms in Obesity and Type 2 Diabetes: Insights from Bariatric/Metabolic Surgery. Obes. Facts 2015, 8, 350-363. [CrossRef]

182. European FMT Working Group; Cammarota, G.; Ianiro, G.; Gasbarrini, A. Faecal microbiota transplantation in clinical practice. Gut 2018, 67, 196-197. [CrossRef]

183. Wang, W.W.; Zhang, Y.; Huang, X.B.; You, N.; Zheng, L.; Li, J. Fecal microbiota transplantation prevents hepatic encephalopathy in rats with carbontetrachloride-induced acute hepatic dysfunction. World J. Gastroenterol. 2017, 23, 6983-6994. [CrossRef]

184. Kao, D.; Roach, B.; Park, H.; Hotte, N.; Madsen, K.; Bain, V.; Tandon, P. Fecal microbiota transplantation in the management of hepatic encephalopathy. Hepatology 2015, 63, 339-340. [CrossRef] [PubMed]

185. Bajaj, J.S.; Kassam, Z.; Fagan, A.; Gavis, E.A.; Liu, E.; Cox, I.J.; Kheradman, R.; Heuman, D.; Wang, J.; Gurry, T.; et al. Fecal microbiota transplant from a rational stool donor improves hepatic encephalopathy: A randomized clinical trial. Hepatology 2017, 66, 1727-1738. [CrossRef]

186. Bajaj, J.S.; Kakiyama, G.; Savidge, T.; Takei, H.; Kassam, Z.A.; Fagan, A.; Gavis, E.A.; Pandak, W.M.; Nittono, H.; Hylemon, P.B.; et al. Antibiotic-Associated Disruption of Microbiota Composition and Function in Cirrhosis Is Restored by Fecal Transplant. Hepatology 2018, 68, 1549-1558. [CrossRef] [PubMed]

187. Garcia-Lezana, T.; Raurell, I.; Bravo, M.; Torres-Arauz, M.; Salcedo, M.T.; Santiago, A.; Schoenenberger, A.; Manichanh, C.; Genescà, J.; Martell, M.; et al. Restoration of a healthy intestinal microbiota normalizes portal hypertension in a rat model of nonalcoholic steatohepatitis. Hepatology 2018, 67, 1485-1498. [CrossRef]

188. Zhou, D.; Pan, Q.; Shen, F.; Cao, H.X.; Ding, W.J.; Chen, Y.W.; Fan, J.G. Total fecal microbiota transplantation alleviates high-fat diet-induced steatohepatitis in mice via beneficial regulation of gut microbiota. Sci. Rep. 2017, 7, 1529. [CrossRef] [PubMed]

189. Craven, L.; Rahman, A.; Nair Parvathy, S.; Beaton, M.; Silverman, J.; Qumosani, K.; Hramiak, I.; Hegele, R.; Joy, T.; Meddings, J.; et al. Allogenic Fecal Microbiota Transplantation in Patients With Nonalcoholic Fatty Liver Disease Improves Abnormal Small Intestinal Permeability: A Randomized Control Trial. Am. J. Gastroenterol. 2020, 115, 1055-1065. [CrossRef]

190. Witjes, J.J.; Smits, L.P.; Pekmez, C.T.; Prodan, A.; Meijnikman, A.S.; Troelstra, M.A.; Bouter, K.E.C.; Herrema, H.; Levin, E.; Holleboom, A.G.; et al. Donor Fecal Microbiota Transplantation Alters Gut Microbiota and Metabolites in Obese Individuals With Steatohepatitis. Hepatol Commun. 2020, 4, 1578-1590. [CrossRef] [PubMed] 